\title{
1 Divergent SARS CoV-2 Omicron-specific T- and B-cell responses in COVID-19 vaccine
}

\section{recipients}

Short title: Omicron-specific immune responses post vaccination

Corine H. GeurtsvanKessel ${ }^{1 *}$, Daryl Geers ${ }^{1+}$, Katharina S. Schmitz ${ }^{1+}$, Anna Z. Mykytyn ${ }^{1+}$, Mart M Lamers $^{1+}$, Susanne Bogers ${ }^{1}$, Lennert Gommers ${ }^{1}$, Roos S.G. Sablerolles ${ }^{2}$, Nella N. Nieuwkoop ${ }^{1}$, Laurine C. Rijsbergen ${ }^{1}$, Laura L.A. van Dijk ${ }^{1}$, Janet de Wilde ${ }^{1}$, Kimberley Alblas ${ }^{1}$, Tim I. Breugem ${ }^{1}$, Bart J.A. Rijnders ${ }^{3}$, Herbert de Jager ${ }^{4}$, Daniela Weiskopf ${ }^{5}$, P. Hugo M. van der Kuy ${ }^{2}$, Alessandro Sette ${ }^{5,6}$, Marion P.G. Koopmans $^{1}$, Alba Grifoni ${ }^{5 \$}$, Bart L. Haagmans ${ }^{1 \$ *}$, Rory D. de Vries ${ }^{1 \$ *}$

\section{Affiliations}

${ }^{1}$ Department of Viroscience, Erasmus MC, Rotterdam, the Netherlands

2 Department of Hospital Pharmacy, Erasmus MC, Rotterdam, Netherlands

${ }^{3}$ Department of Medical Microbiology and Infectious Diseases, Erasmus MC, Rotterdam, The Netherlands

${ }^{4}$ Department of Occupational Health Services, Erasmus MC, Rotterdam, Netherlands

${ }^{5}$ Center for Infectious Disease and Vaccine Research, La Jolla Institute for Immunology, La Jolla, CA 92037, USA

${ }^{6}$ Department of Medicine, Division of Infectious Diseases and Global Public Health, University of California, San Diego (UCSD), La Jolla, CA 92037, USA.

${ }^{\dagger}$ Authors contributed equally

\$ Authors contributed equally

Corresponding authors: Corine H. GeurtsvanKessel (c.geurtsvankessel@erasmusmc.nl), Bart L. Haagmans (ㅁ.haagmans@erasmusmc.nl) and Rory D. de Vries (‥d.devries@erasmusmc.nl).

\section{Acknowledgements}

Chris Groen, Willemijn van der Kleij, Eveline de Haan, Roos Robert, virorunners and colleagues of the Erasmus MC HCW study team are acknowledged for their excellent study support. Faye de Wilt, Djenolan van Mourik, Suzanne van Efferen, Suzanne Hendrickx, Felicity Chandler, and Sandra Scherbeijn are thanked for their technical support and Chantal Reusken for providing the clinical specimen for SARS-CoV-2 Omicron culture. We acknowledge QIAGEN for supporting the study by providing the QuantiFERON SARS-CoV-2 RUO Starter Packs and Extended Packs. QIAGEN had no role in study design, data acquisition and analysis.

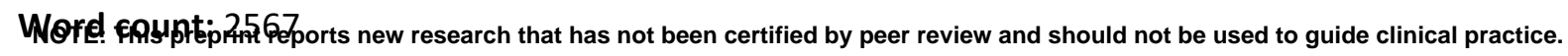


medRxiv preprint doi: https://doi.org/10.1101/2021.12.27.21268416; this version posted December 29, 2021. The copyright holder for this preprint (which was not certified by peer review) is the author/funder, who has granted medRxiv a license to display the preprint in It is made available under a CC-BY 4.0 International license.

\section{Abstract - 250 words}

The severe acute respiratory distress syndrome coronavirus-2 (SARS-CoV-2) Omicron variant (B.1.1.529) is spreading rapidly, even in vaccinated individuals, raising concerns about immune escape. Here, we studied neutralizing antibodies and T-cell responses to SARS-CoV-2 D614G (wildtype, WT), and the B.1.351 (Beta), B.1.617.2 (Delta), and B.1.1.529 (Omicron) variants of concern (VOC) in a cohort of 60 health care workers (HCW) after immunization with ChAdOx-1 S, Ad26.COV2.S, mRNA-1273 or BNT162b2. High binding antibody levels against WT SARS-CoV-2 spike (S) were detected 28 days after vaccination with both mRNA vaccines (mRNA-1273 or BNT162b2), which significantly decreased after 6 months. In contrast, antibody levels were lower after Ad26.COV2.S vaccination but did not wane. Neutralization assays with authentic virus showed consistent cross-neutralization of the Beta and Delta variants in study participants, but Omicron-specific responses were significantly lower or absent (up to a 34-fold decrease compared to D614G). Notably, BNT162b2 booster vaccination after either two mRNA-1273 immunizations or Ad26.COV.2 priming partially restored neutralization of the Omicron variant, but responses were still up to-17-fold decreased compared to D614G. CD4+ T-cell responses were detected up to 6 months after all vaccination regimens; S-specific T-cell responses were highest after mRNA-1273 vaccination. No significant differences were detected between D614G- and variantspecific T-cell responses, including Omicron, indicating minimal escape at the T-cell level. This study shows that vaccinated individuals retain T-cell immunity to the SARS-CoV-2 Omicron variant, potentially balancing the lack of neutralizing antibodies in preventing or limiting severe COVID-19. Booster vaccinations may be needed to further restore Omicron cross-neutralization by antibodies. 
medRxiv preprint doi: https://doi.org/10.1101/2021.12.27.21268416; this version posted December 29, 2021. The copyright holder for this preprint (which was not certified by peer review) is the author/funder, who has granted medRxiv a license to display the preprint in perpetuity.

It is made available under a CC-BY 4.0 International license .

\section{Introduction}

The severe acute respiratory distress syndrome coronavirus-2 (SARS-CoV-2) Omicron variant (B.1.1.529) is characterized by a high number of mutations in the spike (S) protein that have immune evasive potential. Based on transmission characteristics and immune evasion, the World Health Organization (WHO) designated Omicron as a novel variant of concern (VOC). The Omicron variant has been identified worldwide and models have predicted rapid surges of cases that could surpass earlier peaks (1). More data are needed to understand the Omicron disease severity profile, and how severity is impacted by vaccination and pre-existing immunity (2).

The large number of mutations and deletions in the Omicron S protein include alterations in the receptor binding domain ( $R B D)$, the main target of neutralizing antibodies responsible for host cell entry (3-5). It was previously shown for the Beta (B.1.351) and Omicron variant that mutations within the RBD (6-8) and the N-terminal domain (9) can lead to partial escape from neutralizing antibodies. Preliminary data indeed show that there is a concerning reduction in neutralizing antibody titers against Omicron compared to D614G in convalescent and vaccinated individuals, which could be partially restored by booster vaccination (10-12). Additionally, initial show that Omicron is resistant to most antibodies authorized for clinical use (13).

Thus far, neutralizing antibodies are regarded the main correlate of protection against SARS-CoV-2 infection $(14,15)$. The relative contribution of virus-specific T-cells is more difficult to decipher. SARSCoV-2-specific T-cells clear infected cells, thereby contributing to the reduction of viral replication, potentially limiting pathogenicity (16). Previous studies on the impact of mutations in the S protein on T-cell recognition show that VOC S proteins are equally recognized by S-specific T-cells induced by mRNA- $(8,17,18)$ and adenovirus-based $(19)$ vaccines, but studies on T-cell recognition of Omicron are scarce up to present(20). The numerous mutations in the $S$ protein in the Omicron variant potentially disrupt T-cell epitopes (21); however, this negative impact is likely to be significantly smaller than the effect on neutralizing antibody epitopes.

Five vaccines have now been authorized for use in Europe by the European Medicines Agency (EMA); mRNA-based (mRNA-1273 [Moderna], BNT162b2 [Pfizer]), adenovirus vector-based (ChAdOx-1 S [Astrazeneca], Ad26.COV2.S [Janssen]) and the protein-based NVX-CoV2373 (Novavax). These vaccines all use the SARS-CoV-2 S protein of the ancestral strain as template for design, induce robust immune responses, and protect from developing severe coronavirus disease-2019 (COVID-19) (22-25). However, vaccine efficacy differs and may be affected by waning of antibodies and the emergence of variants $(15,26-28)$. In general, boosting immune responses by additional vaccinations efficiently 
medRxiv preprint doi: https://doi.org/10.1101/2021.12.27.21268416; this version posted December 29, 2021. The copyright holder for this preprint (which was not certified by peer review) is the author/funder, who has granted medRxiv a license to display the preprint in It is made available under a CC-BY 4.0 International license.

\section{Results}

\section{Cohort description}

To assess binding antibody and T-cell responses after different vaccination regimens, we collected serum and PBMC from $\mathrm{N}=400$ participants, of which $\mathrm{N}=26$ received two doses ChAdOx-1 $\mathrm{S}, \mathrm{N}=75$ received a single dose Ad26.COV2.S, $\mathrm{N}=199$ received 2 doses of mRNA-1273, and $\mathrm{N}=100$ received 2 doses of BNT162b2. Additionally, we measured responses in $\mathrm{N}=23$ plasma donors with a confirmed WT SARS-CoV-2 infection. Binding antibodies were assessed early (28 days after BNT162b2, mRNA1273 or ChAdOx-1, or 56 days after Ad26.COV2.S) and late (6 months) after vaccination. T-cell responses in whole-blood were assessed at 56 days and 6 months after vaccination (Ad26.COV2.S, $\mathrm{N}=31$ ), 28 days and 6 months after second vaccination (mRNA-1273, $N=39$ ), or exclusively at 6 months after vaccination (ChAdOx-1 S, N=14). Virus neutralization and T-cell assays against VOC were performed in a selection of $\mathrm{N}=15$ participants from each vaccination group at the early and late timepoint. The study design is shown in Figure 1A; participant characteristics are summarized in Table 1.

Participants in the ChAdOx-1 S group were significantly older than participants in other groups ( $p<0.0001$, Kruskal-Wallis with multiple comparisons); other groups were comparable. Additionally, the intervals between first and second vaccination were different for all groups that received two vaccines: median interval for (1) ChAdOx-1 S was 56 days, (2) mRNA-1273 was 28 days, and (3) BNT162b2 was 21 days ( $p<0.0001$ for all comparisons, Kruskal-Wallis with multiple comparisons). 
medRxiv preprint doi: https://doi.org/10.1101/2021.12.27.21268416; this version posted December 29, 2021. The copyright holder for this preprint (which was not certified by peer review) is the author/funder, who has granted medRxiv a license to display the preprint in perpetuity.

It is made available under a CC-BY 4.0 International license .

126 Vaccine-induced antibodies wane after 6 months, except in Ad26.COV2.S vaccinated HCW

127 Highest levels of S-specific binding antibodies were detected 28 days after full vaccination with mRNA1281273 or BNT162b2 (geometric mean titer [GMT] of 3985 and $3030 \mathrm{BAU} / \mathrm{ml}$, respectively). A significant 129 reduction in GMT was observed after 6 months in both groups (Figure 1B, $p<0.0001$, paired T test). 130 Both adenovirus vector-based vaccines induced significantly lower binding antibody titers at 28 days 131 (ChAdOx-1 S) or 56 days (Ad26.COV2.S) after vaccination (GMT of 127 and $163 \mathrm{BAU} / \mathrm{ml}, \mathrm{p}<0.0001$, 132 unpaired T test for all comparisons). Whereas a significant drop in antibody levels was observed in 133 ChAdOx-1 S-vaccinated HCW ( $p<0.0001$, paired T test), the levels remained stable in Ad26.COV2.S134 vaccinated HCW. Despite the levels being stable in Ad26.COV2.S-vaccinated HCW, after 6 months the 135 antibody levels were still significantly higher in HCW vaccinated with an mRNA-based vaccine 136 ( $p<0.0001$, unpaired T test Ad26.COV2.S versus both mRNA-1273 and BNT162b2). Interferon (IFN)/ 137 levels were analyzed in ChAdOx-1 S-, Ad26.COV2.S, and mRNA-1273-vaccinated participants after 138 stimulation of whole-blood as a measure for T-cell activity. mRNA-1273-vaccinated HCW had the 139 highest T-cell responses, but significant decreases were observed 6 months after vaccination $140(p=0.0004$, paired T test). T-cell responses remained stable up to 6 months after Ad26.COV2.S 141 vaccination (Figure 1C).

\section{Significant reduction in Omicron neutralization in convalescent and vaccinated participants}

144 Antibody functionality was measured in an infectious virus neutralization assay with passage 3 SARS145 CoV-2 viruses D614G (WT), B.1.351 (Beta), B.1617.2 (Delta) and B.1.1.529 (Omicron) (Figure 2A). 146 Human airway Calu-3 cells were used for virus propagation and neutralization assays because SARSCoV-2 enters these cells using the TMPRSS2-mediated entry pathway (29-32). This entry pathway is used in vivo, and prevents adaptations in S, commonly observed in Vero cells. At 28 days post vaccination, mRNA-1273 vaccination elicited highest PRNT50 against D614G and all variants, followed by BNT162b2, ChAdOx-1 S, and Ad26.COV2.S vaccination. Delta and Beta variants were neutralized at slightly lower PRNT50 (especially after vaccination with mRNA-based vaccines) and a significant reduction of PRNT50 to Omicron was observed in all groups ( $p<0.0001$ for ChAdOx-1 S, BNT162b2, and mRNA-1273, $p=0.0001$ for Ad26.COV2.S, Friedman test with multiple comparisons). Notably, 13/15 participants in the Ad26.COV2.S group did not neutralize the Omicron variant (Figure 2C).

At 6 months post vaccination, neutralizing antibodies against D614G waned after ChAdOx-1 S, mRNA1273 and BNT162b2 vaccination, but remained stable after Ad26.COV2.S vaccination (Figure 2C, 2D). Differences in GMT PRNT50 values for the different vaccine groups were smaller at this point (GMT 207 for ChAdOx-1, 219 for Ad26.COV2.S, 494 for mRNA-1273, and 197 for BNT162b2). An 11 to 15-fold reduction in PRNT50 to Omicron led to low or completely absent neutralizing antibody levels in all 
medRxiv preprint doi: https://doi.org/10.1101/2021.12.27.21268416; this version posted December 29, 2021. The copyright holder for this preprint (which was not certified by peer review) is the author/funder, who has granted medRxiv a license to display the preprint in perpetuity.

It is made available under a CC-BY 4.0 International license .

161 groups ( $<<0.0001$, Friedman test with multiple comparisons). An 8 -fold reduction in Omicron 162 neutralization was observed in the selection of 15 convalescent (after WT SARS-CoV-2 infection) sera $163 \mathrm{p}=0.0004$, Friedman test with multiple comparisons, Figure 2B). Neutralizing antibodies to the D614G,

164 Beta and Delta variants correlated well to measured binding antibody levels, whereas a lower (but 165 significant) correlation was observed between Omicron-specific neutralizing antibodies and binding antibody levels (Supplemental Figure 1).

Vaccination-induced S-specific CD4+ T-cells equally recognized VOC including Omicron

Besides neutralizing antibodies, we assessed the presence of S-specific T-cell responses by activationinduced marker (AIM) assay in the selection of participants for in-depth assays early and late after vaccination (Figure 3). For the selection of BNT162b2-vaccinated individuals a limited set of PBMC was available ( $\mathrm{N}=5$ out of 15 ). Peripheral blood mononuclear cells (PBMC) were stimulated with either overlapping peptide pools representing the full-length WT S protein, or peptide pools based on the S proteins of the Beta, Delta or Omicron variants (Figure 3A). After stimulation, AIM (OX40 and CD137) expression within CD4+ T-cells was measured by flow cytometry (gating strategy shown in Figure 3B).

S-specific CD4+ T-cells were detected in the majority of vaccinated individuals both early and late after vaccination, with relatively little waning over time (Figure 3C, 3D). Strikingly, CD4+ T-cell responses were consistently higher in mRNA-1273-vaccinated participants, although the BNT162b2-vaccinated cohort had too little power for comparison. We did not observe significant differences between CD4+

181 T-cell responses to WT, Delta, Beta or Omicron S peptide pools at either time point in any vaccination group (with the exception of a small but significant reduction to Delta and Omicron in the ChAdOx-1 S-vaccinated at 6 months, Friedman test with multiple comparisons). In general, a 1.2-to-1.9-fold reduction in T-cell responses to Omicron was observed (with the exception of the BNT162b2 group)

(Figure 3C, 3D).

\section{Increased cross-reactivity of neutralizing antibodies and T-cells against Omicron after boost}

188 Finally, we performed a preliminary analysis of neutralizing antibody and T-cell responses to the different SARS-CoV-2 variants after booster vaccination. HCW vaccinated with either one dose of Ad26.COV2.S ( $\mathrm{N}=15)(33)$ or 2 doses mRNA-1273 $(\mathrm{N}=9)$ were included; both groups were boosted with BNT162b2, either at 85 days after primary vaccination (Ad26.COV2.S) or at 214 days after completion

192 of the primary vaccination series (mRNA-1273) (Figure 4A). Specimen were collected 28 days 193 (Ad26.COV2.S / BNT162b2) or 14 days (2x mRNA-1273/ BNT162b) after boost. Participant 194 characteristics are described in Table 2. 
medRxiv preprint doi: https://doi.org/10.1101/2021.12.27.21268416; this version posted December 29, 2021. The copyright holder for this preprint (which was not certified by peer review) is the author/funder, who has granted medRxiv a license to display the preprint in perpetuity.

It is made available under a CC-BY 4.0 International license .

196 Both boosting strategies led to rapid recall responses and a significant increase in binding antibody

197 levels was observed (Figure 4B); binding antibody levels in the mRNA-1273 boosting regimen reached

198 the highest levels with a GMT of 9331 (versus 3328 in the Ad26.COV2.S-primed individuals). PRNT50

199 after boost were also higher in the mRNA-1273 primed individuals compared to the Ad26.COV2.S-

200 primed individuals (Figure $\mathbf{4 C}$ ). When comparing neutralization of the different VOC, no drop in neutralization of Delta, a two-fold drop in neutralization of Beta, but a significant 17- and 12-fold drop in neutralization of Omicron was still observed $(p<0.0001$ after Ad26.COV2.S priming, $p=0.0002$ after mRNA-1273 priming, Friedman test with multiple comparisons). However, neutralization of Omicron was observed or restored in all boosted individuals (GMT PRNT50 of 189 for Ad26.COV2.S-primed participants, 513 for mRNA-1273-primed individuals). An increase in S-specific T-cells was also observed after booster vaccination of mRNA-1273-primed participants. Interestingly, a 2-fold increase in T-cell responses to Omicron was observed when compared to WT, although this analysis was not powered with 9 participants (Figure 4D).

\section{Discussion}

211 Here, we demonstrate the resistance of the SARS-CoV-2 Omicron (B.1.1.529) variant to neutralizing 212 antibodies induced by mRNA-based or adenovirus vector-based vaccination. We observed up to 30 213 fold reductions of Omicron neutralizing titers when compared to WT SARS-CoV-2. Lower neutralizing 214 antibody levels were previously associated with an increased risk of COVID-19 infection (15), and a higher burden of disease. In contrast, we show that SARS-CoV-2-specific CD4+ T-cell responses were minimally affected by mutations in the Omicron S protein. T-cell activity is thought to confer protection from severe disease, but it remains to be determined whether this is sufficient in the absence of a potent neutralizing antibody response. Importantly, a single BNT162b2 booster immunization induced a substantial increase in Omicron-specific neutralization and CD4+ T cells after priming with either Ad26.COV2.S or mRNA-1273. Neutralization of Omicron was partially restored in individuals without cross-reactive neutralizing antibodies prior to boosting.

We observed high, but transient, levels of SARS-CoV-2-specific binding antibodies after mRNA-based 224 vaccination. Despite the waning of binding antibody levels in vaccinees, affinity maturation of antibodies and a continued increase in SARS-CoV-2-specific memory B cells was previously described between 3 and 6 months after mRNA vaccination (34). These memory B cells are generated in prolonged germinal center reactions (35), and are capable of mounting a rapid recall response upon re-encountering the S protein, either by natural infection or booster vaccination. In contrast, we observed that Ad26.COV2.S vaccination led to antibody responses which showed minimal waning at 6 months (36). This suggests that upon Ad26.COV2.S vaccination maturation of B cells occurs without 
medRxiv preprint doi: https://doi.org/10.1101/2021.12.27.21268416; this version posted December 29, 2021. The copyright holder for this preprint (which was not certified by peer review) is the author/funder, who has granted medRxiv a license to display the preprint in perpetuity.

It is made available under a CC-BY 4.0 International license .

231 further short-term boosting. Neutralizing antibodies are regarded the main correlate of protection

232 against infection with SARS CoV-2 $(14,15)$. The capacity of sera from vaccinated individuals to 233 neutralize the Omicron variant was reduced up to 30-fold, which is in line with another recent study 234 (37). To be protected against symptomatic COVID-19 caused by Omicron, affinity maturation will be essential for the acquisition of broader neutralizing activity of RBD-binding antibodies that were previously formed $(38,39)$. Booster vaccination of Ad26.COV2.S- and mRNA-1273-primed individuals quickly increased S-specific antibodies and restored Omicron neutralization, however Omicron-specific levels were still significantly lower than neutralization of WT. Whether booster vaccinations increase the breadth of the response remains to be determined (36).

Multiple assays to determine the neutralizing capacity of sera are currently employed (40), and the variety of protocols hinders a direct comparison of different studies. We studied VOC-specific neutralization using infectious virus plaque reduction assays. It is known that SARS-CoV-2 propagation on VeroE6 cells, a cell-line routinely used for SARS-CoV-2 neutralization assays, can lead to mutations or deletions in the multibasic cleavage site in the S protein $(29,31,32)$. We therefore grew the viral stocks and performed the neutralization assays on the TMPRSS2 expressing human airway cell-line

\section{Calu-3.}

Thus far, little is known on cross-reactivity of T-cell responses with the Omicron variant(20). Previous studies into cross-reactivity of vaccine-induced T-cells with the Alpha, Beta, Gamma and Delta variant demonstrated minimal reductions in frequency and magnitude of T-cell responses to $\operatorname{VOC}(8,18,19$, $34,41,42)$. Here, we performed a comprehensive analysis of SARS-CoV-2-specific CD4+ T-cells from vaccinated individuals early and late after receiving ChAdOx-1 S, Ad26.COV2.S, mRNA-1273, or BNT162b2 vaccination. In contrast to the humoral responses, we identified durable cellular immune responses that persisted for at least 6 months after either mRNA-based or adenovirus vector-based vaccination. Similar to observations on the level of binding antibodies, mRNA-1273 induced the highest level and most durable SARS-CoV-2-specific T-cell responses. Due to limited availability of PBMC from BNT162b2-vaccinated participants, only 5 donors instead of 15 in the other groups were included, so these results have to be interpreted with caution. However, in line with previous studies into VOCspecific T-cell responses, we show that vaccine-induced $C D 4+T$-cell responses equally recognize the WT, Beta, Delta, and Omicron variant independent of timing or vaccination regimen. Similar analyses have to be performed for CD8+ T-cells, however initial data indicated that these also retain reactivity 263 (20). This fits well with the observation that although Omicron has numerous mutations in the $S$ 264 protein, T-cell epitopes are only minimally affected. A homologous or heterologous booster vaccination with BNT162b2 further increased T-cell responses. 
medRxiv preprint doi: https://doi.org/10.1101/2021.12.27.21268416; this version posted December 29, 2021. The copyright holder for this preprint (which was not certified by peer review) is the author/funder, who has granted medRxiv a license to display the preprint in It is made available under a CC-BY 4.0 International license.

267 Although this study is skewed towards healthy young-adult participants (with the exception of

268 ChAdOx-1 S-vaccinated individuals) and in-depth analyses were performed in a relatively small number

269 of subjects, we show that vaccinated individuals retain T-cell immunity to the Omicron variant,

270 potentially balancing the lack of neutralization antibodies in preventing or limiting severe COVID-19.

271 Furthermore, the fact that booster vaccinations restored and increased the neutralizing capacity

272 against Omicron supports the call for immediate booster campaigns. In the near future, variant-specific

273 booster vaccines may be required to optimally skew the immune responses towards emerging viruses.

274

275 Funding

276 This work was financially supported by the Netherlands Organization for Health Research and

277 Development (ZONMW) grant agreement 10150062010008 to B.L.H. and grant agreement

27810430072110001 to R.D.d.V., C.G.v.K., H.v.d.K and R.S., the Health Holland grants EMCLHS20017 to

279 D.G., L.G., and R.D.d.V. and grant LSHM19136 to B.L.H and the European Union's Horizon 2020

280 research and innovation program under grant no. 101003589 (RECoVER: M.P.G.K.). B.L.H is supported

281 by the NIH/NIAID Centers of Excellence for Influenza Research and Response (CEIRR) under contract

282 75N93021C00014-Icahn School of Medicine at Mt. Sinai. This project has been funded in whole or in

283 part with Federal funds from the National Institute of Allergy and Infectious Diseases, National

284 Institutes of Health, Department of Health and Human Services, under Contract No. 75N93021C00016

285 to A.S. and Contract No. 75N9301900065 to A.S, D.W.

286

\section{Conflict of interest}

288 A.S. is a consultant for Gritstone Bio, Flow Pharma, Arcturus Therapeutics, ImmunoScape, CellCarta,

289 Avalia, Moderna, Fortress and Repertoire. L.J.I. has filed for patent protection for various aspects of T cell epitope and vaccine design work. 
medRxiv preprint doi: https://doi.org/10.1101/2021.12.27.21268416; this version posted December 29, 2021. The copyright holder for this preprint (which was not certified by peer review) is the author/funder, who has granted medRxiv a license to display the preprint in It is made available under a CC-BY 4.0 International license.

\section{Tables}

293

294 Table 1. Participant characteristics.

\begin{tabular}{ccccc}
\hline Cohort & $\mathbf{N}$ & Age (median years, 95\% Cl) & Female (N, \%) & $\begin{array}{c}\text { Vaccination interval } \\
\text { (median days, 95\% Cl) }\end{array}$ \\
\hline Convalescent & 23 & $48(42-58)$ & $4(17 \%)$ & N/A \\
In-depth & 15 & $53(42-62)$ & $1(7 \%)$ & N/A \\
ChAdOx-1 S & 26 & $63(62-64)$ & $17(61 \%)$ & $56(56-70)$ \\
In-depth & 15 & $63(62-64)$ & $9(60 \%)$ & N/A \\
Ad26.COV2.S & 75 & $37(32-43)$ & $62(83 \%)$ & N/A \\
In-depth & 15 & $38(32-50)$ & $13(87 \%)$ & $28(28-28)$ \\
mRNA-1273 & 199 & $41(39-44)$ & $156(78 \%)$ & $25(25-28)$ \\
In-depth & 15 & $34(27-40)$ & $12(80 \%)$ & $21(21-21)$ \\
BNT162b2 & 100 & $40.5(37-45)$ & $66(66 \%)$ & $22(21-25)$ \\
In-depth & 15 & $46(36-53)$ & $11(73 \%)$ & \\
\hline
\end{tabular}


medRxiv preprint doi: https://doi.org/10.1101/2021.12.27.21268416; this version posted December 29, 2021. The copyright holder for this preprint (which was not certified by peer review) is the author/funder, who has granted medRxiv a license to display the preprint in It is made available under a CC-BY 4.0 International license.

296 Table 2. Booster participant characteristics.

\begin{tabular}{lcccc}
\hline Cohort & N & Age (median years, 95\% Cl) & Female (N, \%) & $\begin{array}{c}\text { Vaccination interval } \\
\text { (median days, 95\% Cl) }\end{array}$ \\
\hline Ad26.COV2.S / BNT162b2 & 15 & $37(28-44)$ & $10(67 \%)$ & $88(79-88)$ \\
2x mRNA-1273 / BNT162b2 & 9 & $29(27-40)$ & $7(78 \%)$ & $214(214-219)$ \\
\hline
\end{tabular}

297 
medRxiv preprint doi: https://doi.org/10.1101/2021.12.27.21268416; this version posted December 29, 2021. The copyright holder for this preprint (which was not certified by peer review) is the author/funder, who has granted medRxiv a license to display the preprint in It is made available under a CC-BY 4.0 International license.

A
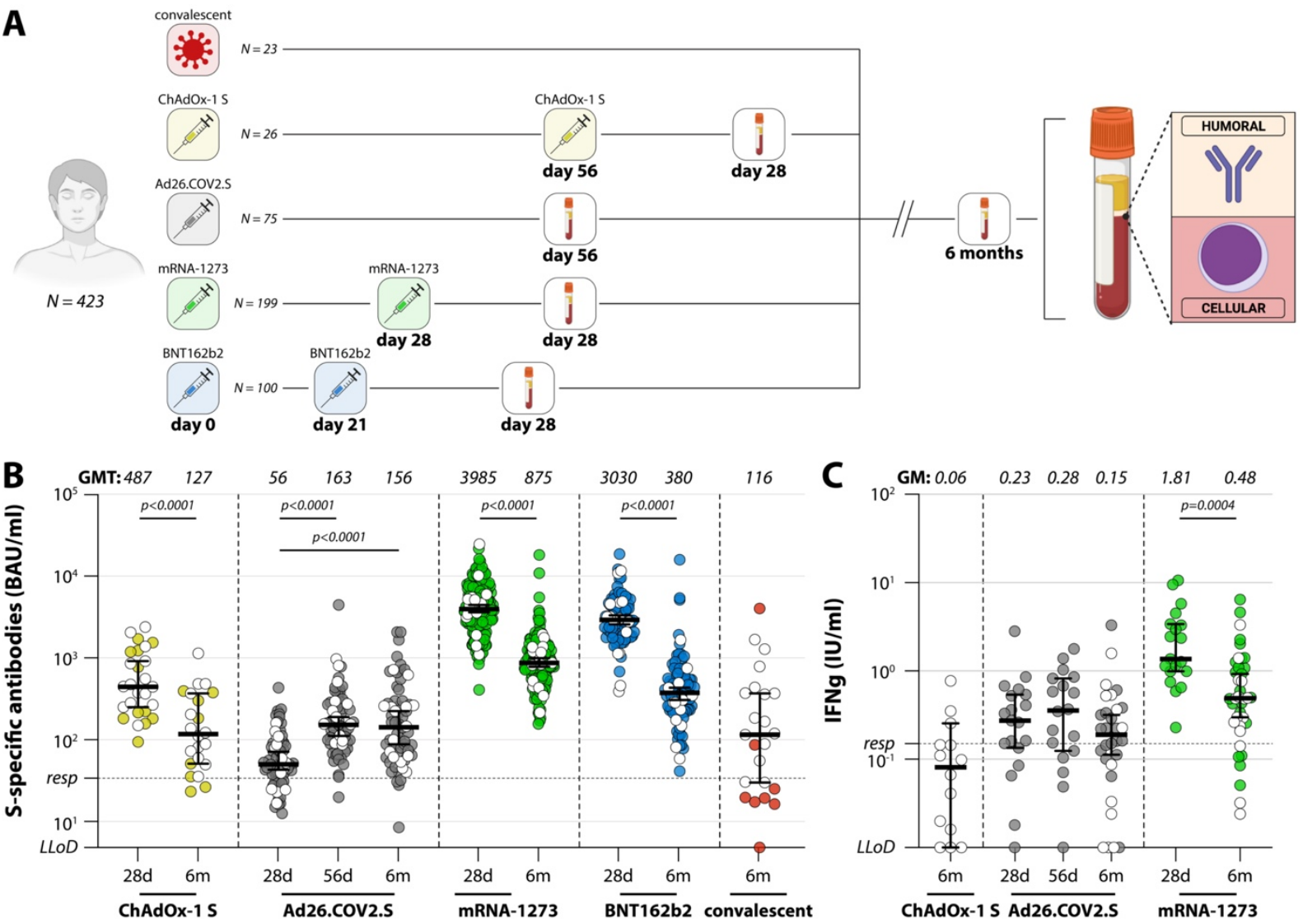

Figure 1. Study design and detection of virus-specific binding antibodies and T-cells. (A) Diagram of the number of included participants and study groups. A total of $\mathrm{N}=423$ participants were included for the analysis of binding antibodies and T-cell responses, responses were measured early and late after completion of the vaccination regimen. Binding antibodies were also assessed in $\mathrm{N}=23$ convalescent participants. (B) Levels of binding S-specific antibodies early (28 days after second vaccination, or 56 days after Ad26.COV2.S vaccination) and late (6 months after completion of vaccination regimen) after vaccination or infection. LLoD is $4.81 \mathrm{BAU} / \mathrm{ml}$, responder (resp) cut-off is $33.8 \mathrm{BAU} / \mathrm{ml}$ (dotted line). Geometric mean titers are indicated above the graph. (C) IFNy levels in plasma after stimulation of whole-blood with peptide pools spanning the S protein (Ag2, QIAGEN) early and late after ChAdOX-1 S, Ad26.COV2.S, or mRNA-1273 vaccination, ChAdOx-1 S responses were exclusively measured at 6

311 months). LLoD is $0.01 \mathrm{IU} / \mathrm{ml}$, responder cut-off is $0.15 \mathrm{IU} / \mathrm{ml}$. Geometric means are indicated above the 312 graph. Comparisons of timepoints within study groups were performed by paired T test. White symbols 313 represent samples selected for in-depth analyses. $L L O D=$ lower limit of detection, $S=S p i k e, B A U=$ 314 binding arbitrary units, GMT = geometric mean titer, $\mathrm{d}=$ days, $\mathrm{m}=$ months, IFNy = interferon gamma. 
medRxiv preprint doi: https://doi.org/10.1101/2021.12.27.21268416; this version posted December 29, 2021. The copyright holder for this preprint (which was not certified by peer review) is the author/funder, who has granted medRxiv a license to display the preprint in perpetuity.

It is made available under a CC-BY 4.0 International license .

A

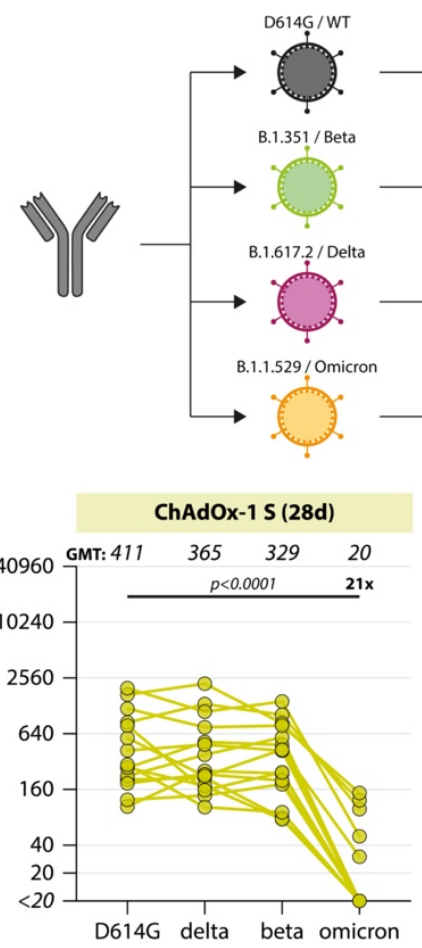

D

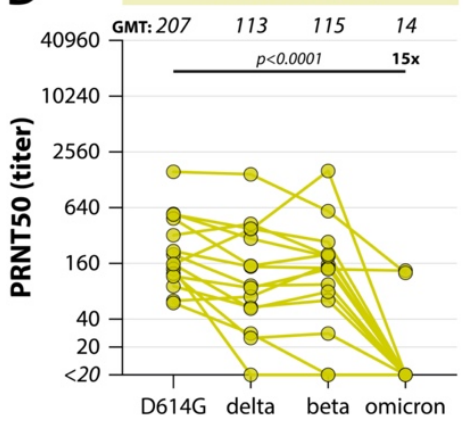

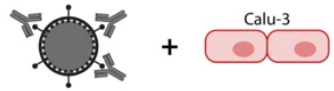

$4+a^{\text {calu-3 }}$
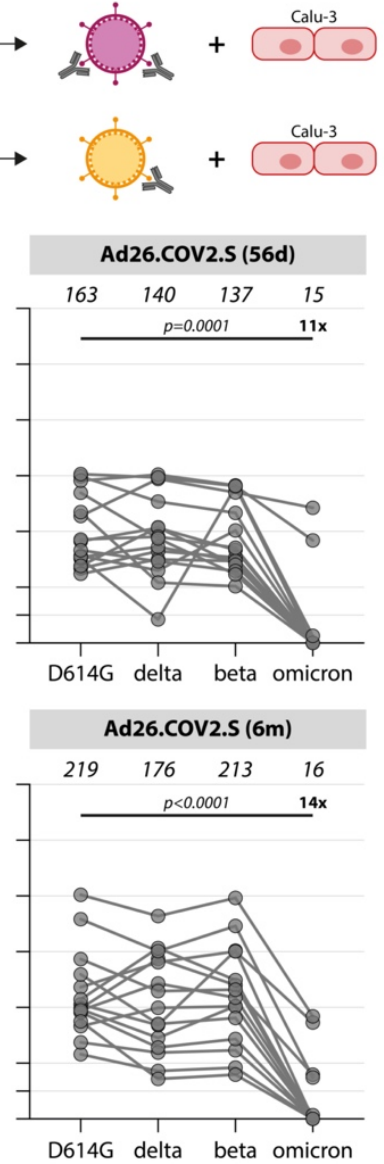

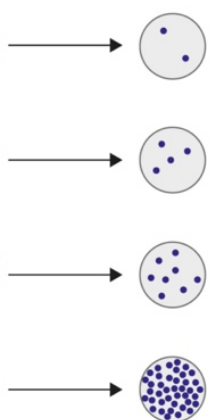

B
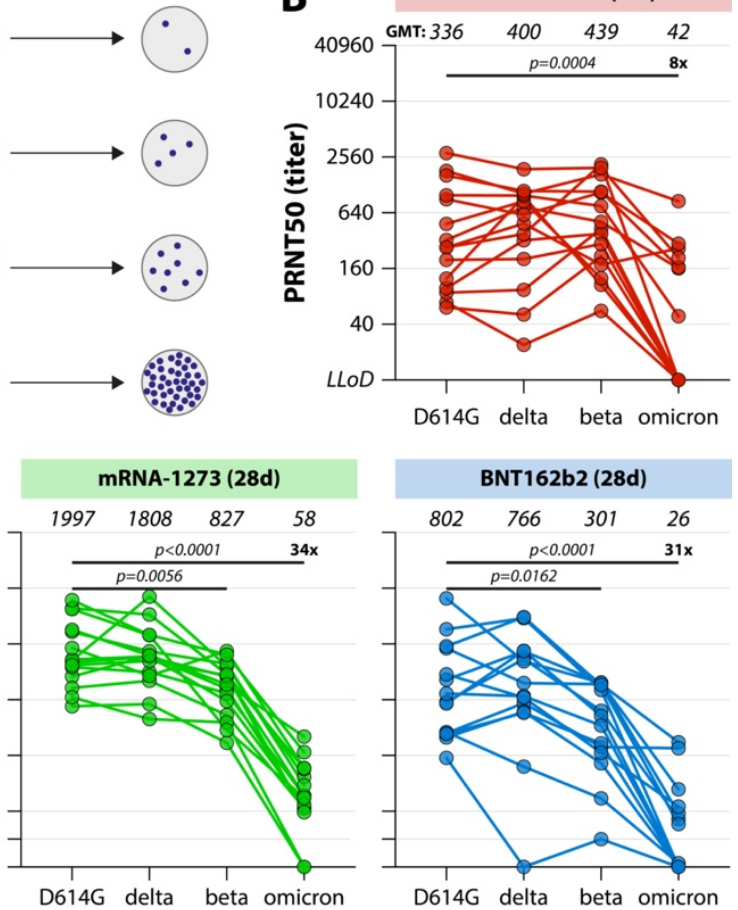

316

Figure 2. SARS-CoV-2 variant-specific neutralizing antibody responses. (A) Schematic overview of the

318 infectious virus PRNT50 assay. Serum samples were pre-incubated with 400 plaque forming units

319 infectious virus for 1 hour, transferred to Calu-3 cells, and N-positive plaques were counted after 8 hours. A PRNT50 (50\% reduction of plaques) was calculated by a proportionate distance formula. (B, C, D) Levels of neutralizing antibodies in convalescent donors after 6 months (B), early after completion of the vaccination regimen (C), and late after completion of the vaccination regimen (D). The lowest serum dilution tested was 1:20, undetectable PRNT50 values $(<20)$ were set at a PRNT50 of 10.

324 Geometric mean titers are indicated above the graphs, fold change reductions are indicated and 325 calculated by dividing the D614G GMT by the Omicron GMT. Comparisons of VOC-specific responses 326 within study groups were performed by Friedman test with multiple comparisons. WT = wildtype, $d=$ days, $m=$ months, PRNT50 = plaque reduction neutralization titer $-50 \%$, 



Figure 3. SARS-CoV-2 variant-specific T-cell responses. (A) Schematic overview of AIM assay. PBMC

were stimulated with different overlapping peptide pools for 20 hours, followed by measurement of upregulation of activation markers by flow cytometry. (B) SARS-CoV-2-specific T-cells were detected

333 by flow cytometry. After setting a time gate, LIVE CD3+ T-cells were gated, singlets were selected, and

334 T-cells were subtyped into CD3+CD4+ and CD3+CD8+ cells. Within the CD4+ and CD8+ T-cells, $T_{\text {naive }}$

335 were defined as CD45RA+CCR7+, $T_{C M}$ as CD45RA-CCR7+, $T_{E M}$ as CD45RA-CCR7-, and TEMRA as

336 CD45RA+CCR7-. S-specific T-cells were detected by co-expression of OX40 and CD137 on CD4+ T-cells

337 in the combination of memory subsets. (C, D) Upregulation of AIM early after completion of the

338 vaccination regimen (C) and late after completion of the vaccination regimen (D). Percentages indicate

339 the percentage of CD4+OX40+CD137+ cells after subtraction of observed background in a DMSO

340 stimulation. Geometric means are indicated above the graphs, fold change reductions are indicated

341 and calculated by dividing the WT Md by the Omicron Md. Comparisons of VOC-specific responses

342 within study groups were performed by Friedman test with multiple comparisons. $M d=$ median, PBMC

$343=$ peripheral blood mononuclear cells, AIM = activation-induced markers, $d=$ days, $m=$ months. 
medRxiv preprint doi: https://doi.org/10.1101/2021.12.27.21268416; this version posted December 29, 2021. The copyright holder for this preprint (which was not certified by peer review) is the author/funder, who has granted medRxiv a license to display the preprint in It is made available under a CC-BY 4.0 International license.

A
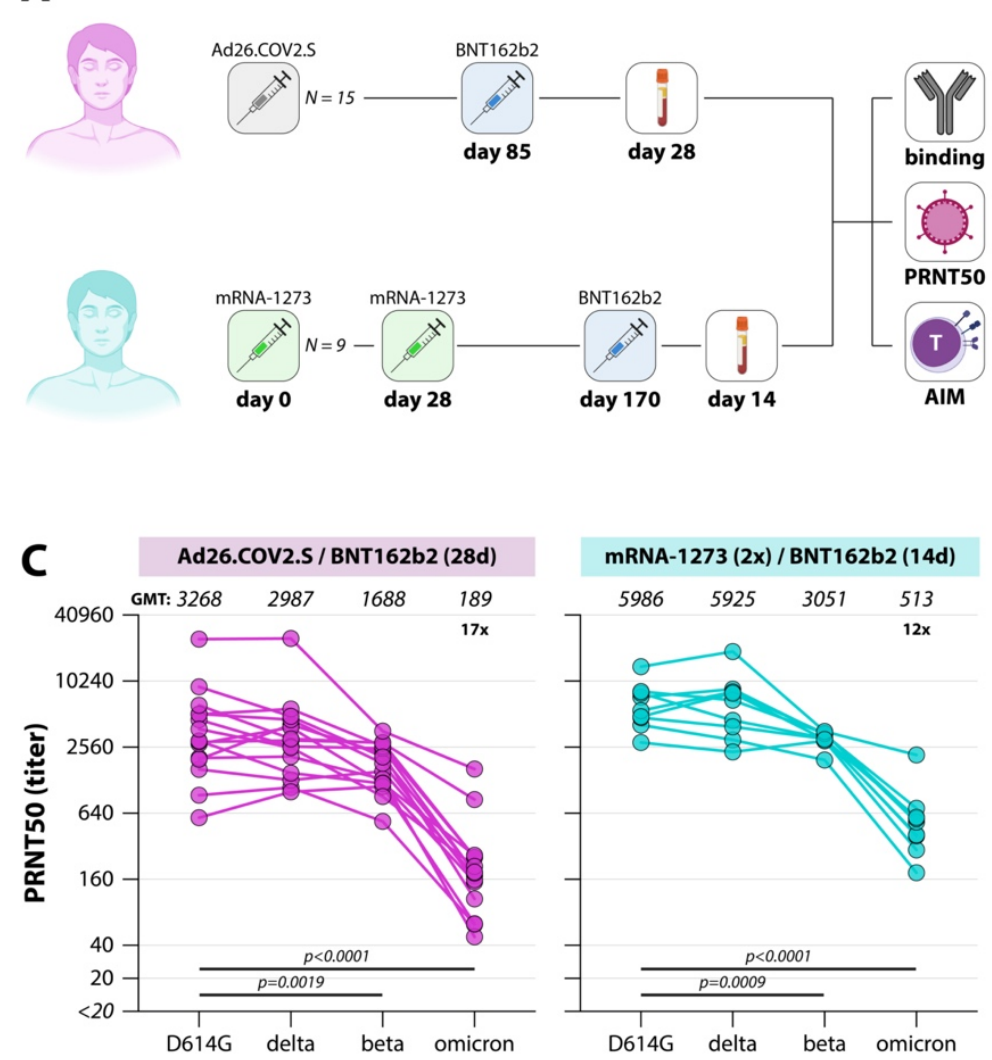
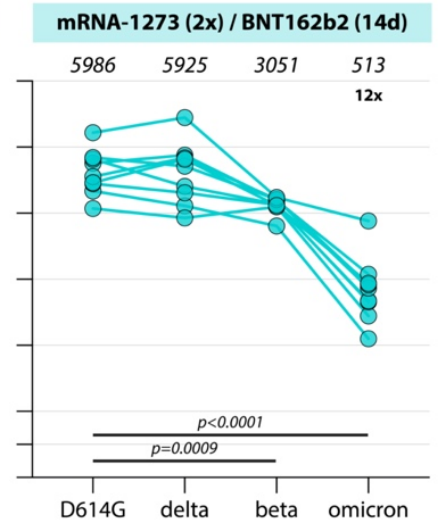

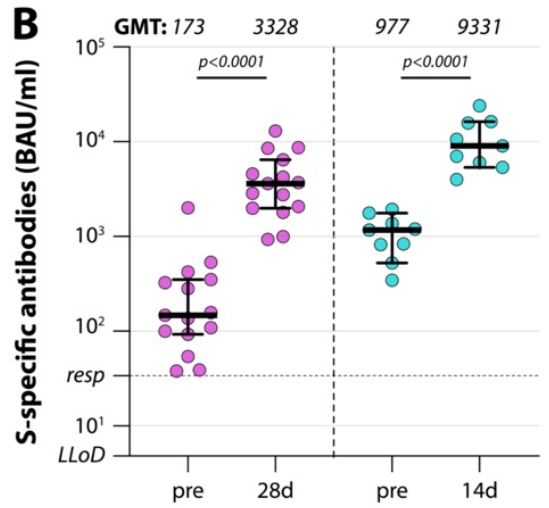

Ad26/BNT mRNA (2x)/BNT
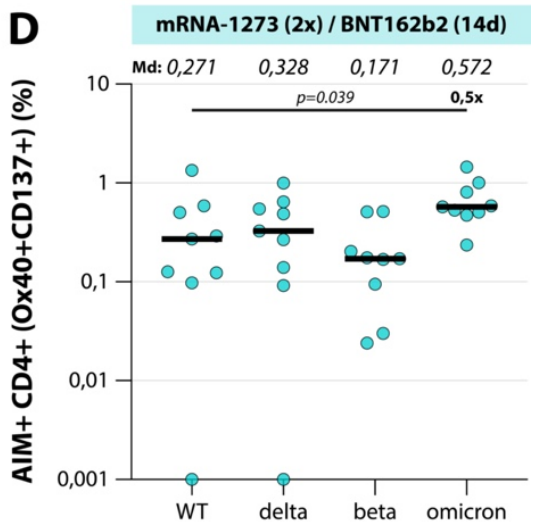

Figure 4. Variant-specific immune responses early booster vaccination. (A) Diagram of the number of

347 included participants in the booster analysis. A total of $\mathrm{N}=24$ participants were included for the analysis

348 of binding antibodies, variant-specific neutralizing antibodies, and variant-specific T-cell responses.

349 Responses were measured early after BNT162b2 booster vaccination. (B) Levels of binding S-specific

350 antibodies early after booster vaccination. LLoD is $4.81 \mathrm{BAU} / \mathrm{ml}$, responder (resp) cut-off is 33.8

$351 \mathrm{BAU} / \mathrm{ml}$ (dotted line). Geometric mean titers are indicated above the graph. Comparisons of timepoints

352 within study groups were performed by paired T test. (C) Levels of neutralizing antibodies in boosted

353 donors. The lowest serum dilution tested was 1:20, undetectable PRNT50 values $(<20)$ were set at a

354 PRNT50 of 10. Geometric mean titers are indicated above the graphs, fold change reductions are

355 indicated and calculated by dividing the D614G GMT by the Omicron GMT. (D) Upregulation of AIM in

356 boosted donors. Percentages indicate the percentage of CD4+OX40+CD137+ cells after subtraction of

357 observed background in a DMSO stimulation. Geometric means or medians are indicated above the

358 graphs, fold change reductions are indicated and calculated by dividing the WT GMT or Md by the

359 Omicron GMT or Md. Comparisons of VOC-specific responses within study groups were performed by

360 Friedman test with multiple comparisons. BAU = binding arbitrary units, GMT = geometric mean titer,

$361 \mathrm{Md}=$ median, $\mathrm{PRNT50}=$ plaque reduction neutralization titer $-50 \%, \mathrm{AIM}=$ activation-induced markers,

$362 \mathrm{~d}=$ days, $\mathrm{m}=$ months. 
medRxiv preprint doi: https://doi.org/10.1101/2021.12.27.21268416; this version posted December 29, 2021. The copyright holder for this preprint (which was not certified by peer review) is the author/funder, who has granted medRxiv a license to display the preprint in It is made available under a CC-BY 4.0 International license.

\section{References}

365 1. S. S. A. Karim, Q. A. Karim, Omicron SARS-CoV-2 variant: a new chapter in the COVID-19 pandemic. Lancet 398, 2126-2128 (2021).

2. W.H.O. (Enhancing Readiness for Omicron (B.1.1.529): Technical Brief and Priority Actions for Member States (who.int) 2021).

3. A. J. Greaney, T. N. Starr, P. Gilchuk, S. J. Zost, E. Binshtein, A. N. Loes, S. K. Hilton, J. Huddleston, Rothlauf, Z. M. Liu, S. P. J. Whelan, R. H. Carnahan, J. E. Crowe, J. D. Bloom, Complete Mapping of Mutations to the SARS-CoV-2 Spike Receptor-Binding Domain that Escape Antibody Recognition. Cell Host Microbe 29, 44-+ (2021).

4. W. T. Harvey, A. M. Carabelli, B. Jackson, R. K. Gupta, E. C. Thomson, E. M. Harrison, C. Ludden, R. Reeve, A. Rambaut, S. J. Peacock, D. L. Robertson, C.-G. U. C.-U. Conso, SARS-CoV-2 variants, spike mutations and immune escape. Nat Rev Microbiol 19, 409-424 (2021).

5. L. Zhang, Q. Li, Z. Liang, T. Li, S. Liu, Q. Cui, J. Nie, Q. Wu, X. Qu, W. Huang, Y. Wang, The significant immune escape of pseudotyped SARS-CoV-2 Variant Omicron. Emerg Microbes

6. W. F. Garcia-Beltran, E. C. Lam, K. St Denis, A. D. Nitido, Z. H. Garcia, B. M. Hauser, J. Feldman, M. N. Pavlovic, D. J. Gregory, M. C. Poznansky, A. Sigal, A. G. Schmidt, A. J. lafrate, V. Naranbhai, immunity. medRxiv, (2021).

7. D. Zhou, W. Dejnirattisai, P. Supasa, C. Liu, A. J. Mentzer, H. M. Ginn, Y. Zhao, H. M. E. Duyvesteyn, A. Tuekprakhon, R. Nutalai, B. Wang, G. C. Paesen, C. Lopez-Camacho, J. SlonCampos, B. Hallis, N. Coombes, K. Bewley, S. Charlton, T. S. Walter, D. Skelly, S. F. Lumley, C. Dold, R. Levin, T. Dong, A. J. Pollard, J. C. Knight, D. Crook, T. Lambe, E. Clutterbuck, S. Bibi, A. Flaxman, M. Bittaye, S. Belij-Rammerstorfer, S. Gilbert, W. James, M. W. Carroll, P. Klenerman,

8. D. Geers, M. C. Shamier, S. Bogers, G. den Hartog, L. Gommers, N. N. Nieuwkoop, K. S. Schmitz, L. C. Rijsbergen, J. A. T. van Osch, E. Dijkhuizen, G. Smits, A. Comvalius, D. van Mourik, T. G. Caniels, M. J. van Gils, R. W. Sanders, B. B. Oude Munnink, R. Molenkamp, H. J. de Jager, B. L. Haagmans, R. L. de Swart, M. P. G. Koopmans, R. S. van Binnendijk, R. D. de Vries, C. H. GeurtsvanKessel, SARS-CoV-2 variants of concern partially escape humoral but not T-cell responses in COVID-19 convalescent donors and vaccinees. Sci Immunol 6, (2021). 
medRxiv preprint doi: https://doi.org/10.1101/2021.12.27.21268416; this version posted December 29, 2021. The copyright holder for this preprint (which was not certified by peer review) is the author/funder, who has granted medRxiv a license to display the preprint in It is made available under a CC-BY 4.0 International license.

9. $\quad$ L. I. Liu, S.; Guo,Y.; Chan,J.F.W.; Wang,M.; Liu, L.; Luo, Y.; Chu H.; Huang, Y.; Nair,M.S.; Yu, J.; Chik, K.K.H.; Yuen, T.T.T. ; Yoon, C.; To, K.K.W.; Chen, H.; Yin, M.T.; Sobieszczyk, M.E.; Huang,Y.; Wang, H.H.; Sheng,Z.; Yuen,K.Y.; Ho, D.D. , Striking Antibody Evasion Manifested by the Omicron Variant of SARS-CoV-2. https://www.biorxiv.org/, (2021).

10. S. J. Cele, L.; Khoury, D.S.; Khan, K.; Moyo-Gwete T.; Tegally, H.; San, J.E.; Cromer, D.; Scheepers C.;Amoako,D.; Karim, F.; Bernstein M.;, Lustig,G.; Archary D.; Smith, M.; Ganga,Y.; Jule,Z.; Reedoy, K.; Hwa, S.H.; Giandhari,J.; Blackburn, J.M.; Gosnell, B.I.; Abdool Karim S.S.; Hanekom W.; NGS-SA, COMMIT-KZN Team, von Gottberg A.; Bhiman, J.; Lessells R.J.; Moosa, MY.S.; Davenport, M.P.; de Oliveira, T.; Moore P.L. , SARS-CoV-2 Omicron has extensive but incomplete escape of Pfizer BNT162b2 elicited neutralization and requires ACE2 for infection. www.medrxiv.org, (2021).

11. H. V. Gruell, K.; Tober-Lau, P.; Hillus, D.;Schommers, P.; Lehmann, C.; Kurth, F.; Sander, L.E.; Klein F., mRNA booster immunization elicits potent neutralizing serum activity against the SARS-CoV-2 Omicron variant. https://www.medrxiv.org/, (2021).

12. I. K. Nemet, L.; Lustig, Y.; Zuckerman, N.S.; Erster, O.; Cohen, C.; Kreiss Y.; Alroy-Preis, S.; RegevYochay, G.; Mendelson, E.; Mandelboim M., Third BNT162b2 vaccination neutralization of SARS-CoV-2 Omicron infection. www.medrxiv.org, (2021).

13. N. H. Ikemura, A.; Higuchi, Y.; Taminishi, S.; Inaba, T.; Matoba S., SARS-CoV-2 Omicron variant escapes neutralization by vaccinated and convalescent sera and therapeutic monoclonal antibodies. https://www.medrxiv.org/, (2021).

14. P. B. Gilbert, D. C. Montefiori, A. B. McDermott, Y. Fong, D. Benkeser, W. Deng, H. Zhou, C. R. Houchens, K. Martins, L. Jayashankar, F. Castellino, B. Flach, B. C. Lin, S. O'Connell, C. McDanal, A. Eaton, M. Sarzotti-Kelsoe, Y. Lu, C. Yu, B. Borate, L. W. P. van der Laan, N. S. Hejazi, C. Huynh, J. Miller, H. M. El Sahly, L. R. Baden, M. Baron, L. De La Cruz, C. Gay, S. Kalams, C. F. Kelley, M. P. Andrasik, J. G. Kublin, L. Corey, K. M. Neuzil, L. N. Carpp, R. Pajon, D. Follmann, R. O. Donis, R. A. Koup, s. Immune Assays Team section, I. T. s. s. Moderna, s. Coronavirus Vaccine Prevention Network /Coronavirus Efficacy Team section, V. P. N. B. T. s. s. United States Government /Co, Immune correlates analysis of the mRNA-1273 COVID-19 vaccine efficacy clinical trial. Science, eab3435 (2021).

15. D. S. Khoury, D. Cromer, A. Reynaldi, T. E. Schlub, A. K. Wheatley, J. A. Juno, K. Subbarao, S. J. Kent, J. A. Triccas, M. P. Davenport, Neutralizing antibody levels are highly predictive of immune protection from symptomatic SARS-CoV-2 infection. Nat Med 27, 1205-1211 (2021). A. Bertoletti, N. Le Bert, M. Qui, A. T. Tan, SARS-CoV-2-specific T cells in infection and vaccination. Cell Mol Immunol 18, 2307-2312 (2021). 
medRxiv preprint doi: https://doi.org/10.1101/2021.12.27.21268416; this version posted December 29, 2021. The copyright holder for this preprint (which was not certified by peer review) is the author/funder, who has granted medRxiv a license to display the preprint in It is made available under a CC-BY 4.0 International license.

17. C. J. Reynolds, C. Pade, J. M. Gibbons, D. K. Butler, A. D. Otter, K. Menacho, M. Fontana, A. Smit, J. E. Sackville-West, T. Cutino-Moguel, M. K. Maini, B. Chain, M. Noursadeghi, U. K. C. I. C. Network, T. Brooks, A. Semper, C. Manisty, T. A. Treibel, J. C. Moon, U. K. C. Investigators, A. M. Valdes, A. McKnight, D. M. Altmann, R. Boyton, Prior SARS-CoV-2 infection rescues B and T cell responses to variants after first vaccine dose. Science, (2021).

18. A. Tarke, J. Sidney, N. Methot, E. D. Yu, Y. Zhang, J. M. Dan, B. Goodwin, P. Rubiro, A. Sutherland, E. Wang, A. Frazier, S. I. Ramirez, S. A. Rawlings, D. M. Smith, R. da Silva Antunes, B. Peters, R. H. Scheuermann, D. Weiskopf, S. Crotty, A. Grifoni, A. Sette, Impact of SARS-CoV2 variants on the total $\mathrm{CD} 4(+)$ and $\mathrm{CD} 8(+) \mathrm{T}$ cell reactivity in infected or vaccinated individuals. Cell Rep Med 2, 100355 (2021).

19. G. Alter, J. Yu, J. Liu, A. Chandrashekar, E. N. Borducchi, L. H. Tostanoski, K. McMahan, C. JacobDolan, D. R. Martinez, A. Chang, T. Anioke, M. Lifton, J. Nkolola, K. E. Stephenson, C. Atyeo, S. Shin, P. Fields, I. Kaplan, H. Robins, F. Amanat, F. Krammer, R. S. Baric, M. Le Gars, J. Sadoff, A. M. de Groot, D. Heerwegh, F. Struyf, M. Douoguih, J. van Hoof, H. Schuitemaker, D. H. Barouch, Immunogenicity of Ad26.COV2.S vaccine against SARS-CoV-2 variants in humans. Nature 596, 268-272 (2021).

20. N. H. Madelon, N.; Sabater Royo,I.; Fontannaz, P.; Breville, G.; Lauper, K.; Goldstein, R.; Grifoni, A.; Sette, A.; Siegrist, C.A.; Finckh, A.; Lalive, P.H.; Didierlaurent,A.M.; Eberhardt, C.S., Omicronspecific cytotoxic T-cell responses are boosted following a third dose of mRNA COVID-19 vaccine in anti-CD20-treated multiple sclerosis patients. www.medrxiv.org, (2021).

21. A. Grifoni, J. Sidney, R. Vita, B. Peters, S. Crotty, D. Weiskopf, A. Sette, SARS-CoV-2 human T cell epitopes: Adaptive immune response against COVID-19. Cell Host Microbe 29, 1076-1092 (2021).

22. L. R. Baden, H. M. El Sahly, B. Essink, K. Kotloff, S. Frey, R. Novak, D. Diemert, S. A. Spector, N. Rouphael, C. B. Creech, J. McGettigan, S. Khetan, N. Segall, J. Solis, A. Brosz, C. Fierro, H. Schwartz, K. Neuzil, L. Corey, P. Gilbert, H. Janes, D. Follmann, M. Marovich, J. Mascola, L. Polakowski, J. Ledgerwood, B. S. Graham, H. Bennett, R. Pajon, C. Knightly, B. Leav, W. Deng, H. Zhou, S. Han, M. Ivarsson, J. Miller, T. Zaks, C. S. Group, Efficacy and Safety of the mRNA1273 SARS-CoV-2 Vaccine. N Engl J Med 384, 403-416 (2021).

23. F. P. Polack, S. J. Thomas, N. Kitchin, J. Absalon, A. Gurtman, S. Lockhart, J. L. Perez, G. Perez Marc, E. D. Moreira, C. Zerbini, R. Bailey, K. A. Swanson, S. Roychoudhury, K. Koury, P. Li, W. V. Kalina, D. Cooper, R. W. Frenck, Jr., L. L. Hammitt, O. Tureci, H. Nell, A. Schaefer, S. Unal, D. B. Tresnan, S. Mather, P. R. Dormitzer, U. Sahin, K. U. Jansen, W. C. Gruber, C. C. T. Group, Safety and Efficacy of the BNT162b2 mRNA Covid-19 Vaccine. N Engl J Med 383, 2603-2615 (2020). 
medRxiv preprint doi: https://doi.org/10.1101/2021.12.27.21268416; this version posted December 29, 2021. The copyright holder for this preprint (which was not certified by peer review) is the author/funder, who has granted medRxiv a license to display the preprint in perpetuity.

It is made available under a CC-BY 4.0 International license.

466

467

468

469

470

471

472

473

474

475

476

477

478

479

480

481

482

483

484

485

486

487

488

489

490

491

492

493

494

495

496

497

498

499

500

24. J. Sadoff, G. Gray, A. Vandebosch, V. Cardenas, G. Shukarev, B. Grinsztejn, P. A. Goepfert, C. Truyers, H. Fennema, B. Spiessens, K. Offergeld, G. Scheper, K. L. Taylor, M. L. Robb, J. Treanor, D. H. Barouch, J. Stoddard, M. F. Ryser, M. A. Marovich, K. M. Neuzil, L. Corey, N. Cauwenberghs, T. Tanner, K. Hardt, J. Ruiz-Guinazu, M. Le Gars, H. Schuitemaker, J. Van Hoof, F. Struyf, M. Douoguih, E. S. Group, Safety and Efficacy of Single-Dose Ad26.COV2.S Vaccine against Covid-19. N Engl J Med 384, 2187-2201 (2021).

25. M. Voysey, S. A. Costa Clemens, S. A. Madhi, L. Y. Weckx, P. M. Folegatti, P. K. Aley, B. Angus, V. L. Baillie, S. L. Barnabas, Q. E. Bhorat, S. Bibi, C. Briner, P. Cicconi, E. A. Clutterbuck, A. M. Collins, C. L. Cutland, T. C. Darton, K. Dheda, C. Dold, C. J. A. Duncan, K. R. W. Emary, K. J. Ewer, A. Flaxman, L. Fairlie, S. N. Faust, S. Feng, D. M. Ferreira, A. Finn, E. Galiza, A. L. Goodman, C. M. Green, C. A. Green, M. Greenland, C. Hill, H. C. Hill, I. Hirsch, A. Izu, D. Jenkin, C. C. D. Joe, S. Kerridge, A. Koen, G. Kwatra, R. Lazarus, V. Libri, P. J. Lillie, N. G. Marchevsky, R. P. Marshall, A. V. A. Mendes, E. P. Milan, A. M. Minassian, A. McGregor, Y. F. Mujadidi, A. Nana, S. D. Padayachee, D. J. Phillips, A. Pittella, E. Plested, K. M. Pollock, M. N. Ramasamy, A. J. Ritchie, H. Robinson, A. V. Schwarzbold, A. Smith, R. Song, M. D. Snape, E. Sprinz, R. K. Sutherland, E. C. Thomson, M. E. Torok, M. Toshner, D. P. J. Turner, J. Vekemans, T. L. Villafana, T. White, C. J. Williams, A. D. Douglas, A. V. S. Hill, T. Lambe, S. C. Gilbert, A. J. Pollard, C. V. T. G. Oxford, Single-dose administration and the influence of the timing of the booster dose on immunogenicity and efficacy of ChAdOx1 nCoV-19 (AZD1222) vaccine: a pooled analysis of four randomised trials. Lancet 397, 881-891 (2021).

26. J. S. Tregoning, K. E. Flight, S. L. Higham, Z. Wang, B. F. Pierce, Progress of the COVID-19 vaccine effort: viruses, vaccines and variants versus efficacy, effectiveness and escape. Nat Rev Immunol 21, 626-636 (2021).

27. J. Lopez Bernal, N. Andrews, C. Gower, E. Gallagher, R. Simmons, S. Thelwall, J. Stowe, E. Tessier, N. Groves, G. Dabrera, R. Myers, C. N. J. Campbell, G. Amirthalingam, M. Edmunds, M. Zambon, K. E. Brown, S. Hopkins, M. Chand, M. Ramsay, Effectiveness of Covid-19 Vaccines against the B.1.617.2 (Delta) Variant. N Engl J Med 385, 585-594 (2021).

28. K. L. Bajema, R. M. Dahl, M. M. Prill, E. Meites, M. C. Rodriguez-Barradas, V. C. Marconi, D. O. Beenhouwer, S. T. Brown, M. Holodniy, C. Lucero-Obusan, G. Rivera-Dominguez, R. G. Morones, A. Whitmire, E. B. Goldin, S. L. Evener, M. Tremarelli, S. Tong, A. J. Hall, S. J. Schrag, M. McMorrow, M. Kobayashi, J. R. Verani, D. Surie, C. Supernova, G. Surveillance, E. Surveillance Platform for, V. A. C.-S. G. Respiratory Infectious Organisms at the, Effectiveness of COVID-19 mRNA Vaccines Against COVID-19-Associated Hospitalization - Five Veterans Affairs Medical Centers, United States, February 1-August 6, 2021. MMWR Morb Mortal Wkly Rep 70, 1294-1299 (2021). 
medRxiv preprint doi: https://doi.org/10.1101/2021.12.27.21268416; this version posted December 29, 2021. The copyright holder for this preprint (which was not certified by peer review) is the author/funder, who has granted medRxiv a license to display the preprint in It is made available under a CC-BY 4.0 International license.

29. M. M. Lamers, A. Z. Mykytyn, T. I. Breugem, Y. Wang, D. C. Wu, S. Riesebosch, P. B. van den Doel, D. Schipper, T. Bestebroer, N. C. Wu, B. L. Haagmans, Human airway cells prevent SARSCoV-2 multibasic cleavage site cell culture adaptation. Elife 10, (2021).

30. A. Z. Mykytyn, T. I. Breugem, S. Riesebosch, D. Schipper, P. B. van den Doel, R. J. Rottier, M. M. Lamers, B. L. Haagmans, SARS-CoV-2 entry into human airway organoids is serine proteasemediated and facilitated by the multibasic cleavage site. Elife 10, (2021).

31. M. Hoffmann, H. Kleine-Weber, S. Schroeder, N. Kruger, T. Herrler, S. Erichsen, T. S. Schiergens, G. Herrler, N. H. Wu, A. Nitsche, M. A. Muller, C. Drosten, S. Pohlmann, SARS-CoV-2 Cell Entry Depends on ACE2 and TMPRSS2 and Is Blocked by a Clinically Proven Protease Inhibitor. Cell 181, 271-280 e278 (2020).

32. N. S. Ogando, T. J. Dalebout, J. C. Zevenhoven-Dobbe, R. Limpens, Y. van der Meer, L. Caly, J. Druce, J. J. C. de Vries, M. Kikkert, M. Barcena, I. Sidorov, E. J. Snijder, SARS-coronavirus-2 replication in Vero E6 cells: replication kinetics, rapid adaptation and cytopathology. J Gen Virol 101, 925-940 (2020).

33. R. S. G. Sablerolles, A. Goorhuis, C. H. GeurtsvanKessel, R. D. de Vries, A. L. W. Huckriede, M. P. G. Koopmans, M. Lafeber, D. F. Postma, D. van Baarle, L. G. Visser, V. Dalm, N. A. Kootstra, W. J. R. Rietdijk, P. H. M. van der Kuy, Heterologous Ad26.COV2.S Prime and mRNA-Based Boost COVID-19 Vaccination Regimens: The SWITCH Trial Protocol. Front Immunol 12, 753319 (2021).

34. R. R. Goel, M. M. Painter, S. A. Apostolidis, D. Mathew, W. Meng, A. M. Rosenfeld, K. A. Lundgreen, A. Reynaldi, D. S. Khoury, A. Pattekar, S. Gouma, L. Kuri-Cervantes, P. Hicks, S. Dysinger, A. Hicks, H. Sharma, S. Herring, S. Korte, A. E. Baxter, D. A. Oldridge, J. R. Giles, M. E. Weirick, C. M. McAllister, M. Awofolaju, N. Tanenbaum, E. M. Drapeau, J. Dougherty, S. Long, K. D'Andrea, J. T. Hamilton, M. McLaughlin, J. C. Williams, S. Adamski, O. Kuthuru, U. P. C. P. U. dagger, I. Frank, M. R. Betts, L. A. Vella, A. Grifoni, D. Weiskopf, A. Sette, S. E. Hensley, M. P. Davenport, P. Bates, E. T. Luning Prak, A. R. Greenplate, E. J. Wherry, mRNA vaccines induce durable immune memory to SARS-CoV-2 and variants of concern. Science 374, abm0829 (2021).

35. J. S. Turner, J. A. O'Halloran, E. Kalaidina, W. Kim, A. J. Schmitz, J. Q. Zhou, T. Lei, M. Thapa, R. E. Chen, J. B. Case, F. Amanat, A. M. Rauseo, A. Haile, X. Xie, M. K. Klebert, T. Suessen, W. D. Middleton, P. Y. Shi, F. Krammer, S. A. Teefey, M. S. Diamond, R. M. Presti, A. H. Ellebedy, SARSCoV-2 mRNA vaccines induce persistent human germinal centre responses. Nature 596, 109$113(2021)$.

D. H. Barouch, K. E. Stephenson, J. Sadoff, J. Yu, A. Chang, M. Gebre, K. McMahan, J. Liu, A. Chandrashekar, S. Patel, M. Le Gars, A. M. de Groot, D. Heerwegh, F. Struyf, M. Douoguih, J. 
medRxiv preprint doi: https://doi.org/10.1101/2021.12.27.21268416; this version posted December 29, 2021. The copyright holder for this preprint (which was not certified by peer review) is the author/funder, who has granted medRxiv a license to display the preprint in perpetuity.

It is made available under a CC-BY 4.0 International license .

van Hoof, H. Schuitemaker, Durable Humoral and Cellular Immune Responses 8 Months after Ad26.COV2.S Vaccination. N Engl J Med 385, 951-953 (2021).

37. M. Hoffmann, Krüger, N.; Schulz, S.; Cossmann, A.; Rocha, C.; Kempf, A.;, I. G. Nehlmeier, L.; Moldenhauer, A.-S..; Winkler, M.S.; Lier, M.; Dopfer-Jablonka, A.;, Jäck,, G. M. N. P. H.-M.; Behrens, S., The Omicron variant is highly resistant against antibody-mediated neutralization - implications for control of the COVID-19 pandemic. Cell, (2021).

38. M. G. de Mattos Barbosa, H. Liu, D. Huynh, G. Shelley, E. T. Keller, B. T. Emmer, E. Sherman, D. Ginsburg, A. A. Kennedy, A. W. Tai, C. Wobus, C. Mirabeli, T. M. Lanigan, M. Samaniego, W. Meng, A. M. Rosenfeld, E. T. L. Prak, J. L. Platt, M. Cascalho, IgV somatic mutation of human anti-SARS-CoV-2 monoclonal antibodies governs neutralization and breadth of reactivity. $J C I$ Insight 6, (2021).

39. C. Gaebler, Z. Wang, J. C. C. Lorenzi, F. Muecksch, S. Finkin, M. Tokuyama, A. Cho, M. Jankovic, D. Schaefer-Babajew, T. Y. Oliveira, M. Cipolla, C. Viant, C. O. Barnes, Y. Bram, G. Breton, T. Hagglof, P. Mendoza, A. Hurley, M. Turroja, K. Gordon, K. G. Millard, V. Ramos, F. Schmidt, Y. Weisblum, D. Jha, M. Tankelevich, G. Martinez-Delgado, J. Yee, R. Patel, J. Dizon, C. UnsonO'Brien, I. Shimeliovich, D. F. Robbiani, Z. Zhao, A. Gazumyan, R. E. Schwartz, T. Hatziioannou, P. J. Bjorkman, S. Mehandru, P. D. Bieniasz, M. Caskey, M. C. Nussenzweig, Evolution of antibody immunity to SARS-CoV-2. Nature 591, 639-644 (2021).

40. A. M. Chmielewska, A. Czarnota, K. Bienkowska-Szewczyk, K. Grzyb, Immune response against SARS-CoV-2 variants: the role of neutralization assays. NPJ Vaccines 6, 142 (2021).

41. R. Keeton, S. I. Richardson, T. Moyo-Gwete, T. Hermanus, M. B. Tincho, N. Benede, N. P. Manamela, R. Baguma, Z. Makhado, A. Ngomti, T. Motlou, M. Mennen, L. Chinhoyi, S. Skelem, H. Maboreke, D. Doolabh, A. Iranzadeh, A. D. Otter, T. Brooks, M. Noursadeghi, J. C. Moon, A. Grifoni, D. Weiskopf, A. Sette, J. Blackburn, N. Y. Hsiao, C. Williamson, C. Riou, A. Goga, N. Garrett, L. G. Bekker, G. Gray, N. A. B. Ntusi, P. L. Moore, W. A. Burgers, Prior infection with SARS-CoV-2 boosts and broadens Ad26.COV2.S immunogenicity in a variant-dependent manner. Cell Host Microbe 29, 1611-1619 e1615 (2021).

42. F. Melo-Gonzalez, J. A. Soto, L. A. Gonzalez, J. Fernandez, L. F. Duarte, B. M. Schultz, N. M. S. Galvez, G. A. Pacheco, M. Rios, Y. Vazquez, D. Rivera-Perez, D. Moreno-Tapia, C. Iturriaga, O. P. Vallejos, R. V. Berrios-Rojas, G. Hoppe-Elsholz, M. Urzua, N. Bruneau, R. A. Fasce, J. Mora, A. Grifoni, A. Sette, D. Weiskopf, G. Zeng, W. Meng, J. V. Gonzalez-Aramundiz, P. A. Gonzalez, K. Abarca, E. Ramirez, A. M. Kalergis, S. M. Bueno, Recognition of Variants of Concern by Antibodies and T Cells Induced by a SARS-CoV-2 Inactivated Vaccine. Front Immunol 12, 747830 (2021). 


\section{Divergent SARS CoV-2 Omicron-specific T- and B-cell responses in COVID-19 vaccine}

\section{2 recipients}

3

4 Short title: Omicron-specific immune responses post vaccination

6 Corine H. GeurtsvanKessel ${ }^{1 *}$, Daryl Geers ${ }^{1+}$, Katharina S. Schmitz ${ }^{1+}$, Anna Z. Mykytyn ${ }^{1+}$, Mart M

7 Lamers $^{1+}$, Susanne Bogers ${ }^{1}$, Lennert Gommers ${ }^{1}$, Roos S.G. Sablerolles ${ }^{2}$, Nella N. Nieuwkoop ${ }^{1}$, Laurine C.

8 Rijsbergen ${ }^{1}$, Laura L.A. van Dijk ${ }^{1}$, Janet de Wilde ${ }^{1}$, Kimberley Alblas ${ }^{1}$, Tim I. Breugem ${ }^{1}$, Bart J.A. Rijnders ${ }^{3}$,

9 Herbert de Jager ${ }^{4}$, Daniela Weiskopf ${ }^{5}$, P. Hugo M. van der Kuy², Alessandro Sette ${ }^{5,6}$, Marion P.G.

10 Koopmans ${ }^{1}$, Alba Grifoni ${ }^{5 \$}$, Bart L. Haagmans ${ }^{15 *}$, Rory D. de Vries ${ }^{1 \$ *}$

12 Affiliations

$13{ }^{1}$ Department of Viroscience, Erasmus MC, Rotterdam, the Netherlands

142 Department of Hospital Pharmacy, Erasmus MC, Rotterdam, Netherlands

$15{ }^{3}$ Department of Medical Microbiology and Infectious Diseases, Erasmus MC, Rotterdam, The Netherlands

$16{ }^{4}$ Department of Occupational Health Services, Erasmus MC, Rotterdam, Netherlands

$17{ }^{5}$ Center for Infectious Disease and Vaccine Research, La Jolla Institute for Immunology, La Jolla, CA 92037, USA

$18{ }^{6}$ Department of Medicine, Division of Infectious Diseases and Global Public Health, University of California, San 19 Diego (UCSD), La Jolla, CA 92037, USA.

$20+$ Authors contributed equally

21 \$ Authors contributed equally

23 Corresponding authors: Corine H. GeurtsvanKessel (c.geurtsvankessel@erasmusmc.nl), Bart L. 24 Haagmans (b.haagmans@erasmusmc.nl) and Rory D. de Vries (r.d.devries@erasmusmc.nl). 
medRxiv preprint doi: https://doi.org/10.1101/2021.12.27.21268416; this version posted December 29, 2021. The copyright holder for this preprint (which was not certified by peer review) is the author/funder, who has granted medRxiv a license to display the preprint in perpetuity.

It is made available under a CC-BY 4.0 International license .

Supplementary Material

Methods

\section{Ethics statement}

Samples from three different trials (HCW, ConCOVID, and SWITCH) were analysed in the scope of this study (Supplemental Table 1). The HCW study was approved by the institutional review board of the Erasmus MC (medical ethical committee, MEC-2020-0264) (1). The ConCOVID trial was also approved by the institutional review board of the Erasmus MC (MEC 2020-0228). The study was registered at clinicaltrials.gov (NCT04342182) (2). The SWITCH trial was approved by the institutional review board of the Erasmus MC (MEC 2021-0132) and local review boards of participating centres. The study was registered at clinicaltrials.gov (NCT04927936) (3). All studies adhere to the principles of the Declaration of Helsinki, and written informed consent was obtained from every participant, patient or legal representative.

\section{Study design}

A prospective cohort study of health care workers (HCW) at Erasmus MC was initiated in 2020, with a focus on immunity against SARS CoV-2 after symptomatic presentation to the occupational health services. From January 2021, HCW in the Netherlands were offered vaccination with one of the 4 approved vaccines in the Netherlands (ChAdOx-1 S, Ad26.COV2.S, mRNA-1273 and BNT162b2), participants of the HCW study were invited for the follow up study in which immune responses upon vaccination were studied. From December 2021, HCW in the study were invited for a follow up study after booster vaccination with BNT162b2. Serum and PBMC samples from all vaccinated participants of the HCW study were obtained 28 days and 6 months after second vaccination (with the exception of Ad26.COV2.S vaccinated HCW, samples were obtained 56 days after first vaccination). $\mathrm{HCW}$ were vaccinated with (1) ChAdOx-1 S / ChAdOx-1S (56 day interval), (2) Ad26.COV2.S, (3) mRNA-1273 / mRNA-1273 (28 day interval), or BNT162b2 / BNT162b2 (21 days interval) (Figure 1A). Additional serum and PBMC samples were obtained from 9 mRNA1273 / mRNA-1273-primed participants at 14 days after booster vaccination with BNT162b2. Participants of the SWITCH trial were vaccinated with Ad26.COV2.S, followed by a BNT162b2 boost ( 85 day interval) (3). Serum samples were obtained 28 days after the booster vaccination (Figure 4A). Participants of the HCW and SWITCH trial had no history of previous SARS-CoV-2 infection, as confirmed by absence of $\mathrm{N}$-specific antibodies and / or S-specific antibodies pre-vaccination at baseline. Serum samples from convalescent PCR-confirmed COVID-19 patients were obtained 6 months after infection in the scope of the ConCOVID study, in which study participants were recruited to participate as plasma donors (2). These patients were infected during 
medRxiv preprint doi: https://doi.org/10.1101/2021.12.27.21268416; this version posted December 29, 2021. The copyright holder for this preprint (which was not certified by peer review) is the author/funder, who has granted medRxiv a license to display the preprint in perpetuity.

It is made available under a CC-BY 4.0 International license .

the first wave in 2020, all with a D614G SARS-CoV-2. In-depth neutralization and T-cell assays were performed on a selection of $\mathrm{N}=15$ participants from each group (Table 1, Table 2). The selection of participants for in-depth analyses was based on availability of longitudinal PBMC samples and the distribution of antibody responses (Figure 1B, 1C).

\section{Serum and PBMC isolation}

Serum was collected in 10-ml tubes without anticoagulant, centrifuged at $2500 \mathrm{rpm}$ for $15 \mathrm{~min}$, aliquoted, and stored at $-20^{\circ} \mathrm{C}$ for further experiments. PBMCs were isolated from blood collected in $\mathrm{K}_{3}$ EDTA or Lithium Heparin tubes by density gradient centrifugation. Briefly, blood was layered on a density gradient (Lymphoprep, STEMCELL Technologies), and PBMCs were separated by centrifuging at $2000 \mathrm{rpm}$ for $30 \mathrm{~min}$. PBMCs were washed four times in PBS and subsequently frozen in liquid nitrogen in 90\% fetal bovine serum (FBS) with 10\% dimethyl sulfoxide (DMSO; Honeywell) until use in stimulation assays.

\section{Detection of S-specific binding antibodies}

Binding antibodies against the SARS-CoV-2 Spike (S) protein were measured by Liaison SARS-CoV-2 TrimericS IgG assay (DiaSorin, Italy), with a lower limit of detection of $4.81 \mathrm{BAU} / \mathrm{ml}$ and a cut-off for positivity at $33.8 \mathrm{BAU} / \mathrm{ml}$. The assay was performed following the manufacturer's instructions.

\section{IFNy release assay (IGRA)}

The SARS-CoV-2-specific T cell response was measured by commercially available IFNy Release Assay (IGRA, QuantiFERON, Qiagen) in whole blood as previously described and following the manufacturer's description (4). In short, heparinized whole blood was incubated with three different SARS-CoV-2 antigens for 20-24h using a combination of peptides stimulating both $\mathrm{CD}^{+}$and $\mathrm{CD} 8^{+} \mathrm{T}$-cells (Ag1, Ag2, Ag3, QuantiFERON, QIAGEN). After incubation, plasma was obtained and IFNy production in response to the antigens was measured by ELISA. Results are expressed in IU IFNy / $\mathrm{ml}$ after subtraction of the NIL control values as interpolated from a standard calibration curve. Lower limit of detection in this assay is set at $0.01 \mathrm{IU} / \mathrm{ml}$, responder cut-off is $0.15 \mathrm{IU} / \mathrm{m}$ ). IFNy production after stimulation with Ag2, containing peptides covering the S protein, was shown in this study.

\section{Virus culture and deep-sequencing}

SARS-CoV-2 isolates were grown to passage 3 on Calu-3 (ATCC HTB-55) cells in Advanced DMEM/F12 (Gibco), supplemented with HEPES, Glutamax, penicillin (100 IU/mL) and streptomycin (100 IU/mL) at $37^{\circ} \mathrm{C}$ in a humidified $\mathrm{CO}_{2}$ incubator. Infections were performed at a multiplicity of infection (MOI) of 0.01 and virus was harvested after 72 hours. The culture supernatant was cleared by centrifugation at 
medRxiv preprint doi: https://doi.org/10.1101/2021.12.27.21268416; this version posted December 29, 2021. The copyright holder for this preprint (which was not certified by peer review) is the author/funder, who has granted medRxiv a license to display the preprint in perpetuity.

It is made available under a CC-BY 4.0 International license .

$1000 \times \mathrm{g}$ for $5 \mathrm{~min}$ and stored at $-80^{\circ} \mathrm{C}$ in aliquots. Stock titers were determined by incubating 10 -fold dilutions of virus stock in OptiMEM at $37^{\circ} \mathrm{C}$ for 1 hour, after which they were transferred onto Calu-3 cells and incubated for 8 hours at $37^{\circ} \mathrm{C}$ in a humidified $\mathrm{CO}_{2}$ incubator. Next, cells were fixed with $4 \%$ formalin, permeabilized in $70 \%$ ethanol, after which infected cells were stained with polyclonal rabbit anti-SARS-CoV-2 nucleocapsid antibody (Sino Biological) and a secondary goat anti-rabbit IgG AF488 (Invitrogen). Stained plates were scanned on the Amersham Typhoon Biomolecular Imager (channel Cy2; resolution $10 \mu \mathrm{m}$; GE Healthcare) and the number of infected cells was determined to calculate the stock titer per milliliter. All work with infectious SARS-CoV-2 was performed in a Class II Biosafety Cabinet under BSL-3 conditions at Erasmus Medical Center.

Viral genome sequences were determined using Illumina deep-sequencing. RNA was extracted using AMPure XP beads and CDNA was generated using Protoscriptll reverse transcriptase enzyme (New England, BiotechnologyBioLabs) according to the manufacturer's protocol (5). Samples were amplified using the QIAseq SARS-CoV-2 Primer Panel (Qiagen). Amplicons were purified with 0.8x AMPure XP beads and 100ng of DNA was converted to paired-end Illumina sequencing libraries using the KAPA HyperPlus library preparation kit (Roche) with the KAPA unique dual-indexed adapters (Roche) as per manufacturers recommendations. The barcode-labeled samples were pooled and analyzed on an Illumina sequencer V3 MiSeq flowcell (2×300 cycles). Sequences were analyzed using CLC Genomics Workbench 21.0.3. The 614G virus (clade B; isolate Bavpat-1; European Virus Archive Global \#026 V03883) passage 3 sequence was identical to the passage 1 (kindly provided by Dr. Christian Drosten) and no minor variants $>20 \%$ were detected. The beta variant (clade B.1.351) passage 3 sequence contained two mutations compared the original respiratory specimen: one synonymous mutations C13860T (Wuhan-1 position) in ORF1ab and a L71P change in the E gene (T26456C, Wuhan-1 position). No other minor variants $>20 \%$ were detected. The delta (clade B.1.617.2) and omicron (clade B.1.1.529) variant passage 3 sequences were identical to the original respiratory specimens and no minor variants $>20 \%$ were detected. Due to primer mismatches in the S1 region of the omicron spike gene, amplicons 72, 73, 75 and 76 were sequenced at low coverage. Therefore, the S1 regions of the original respiratory specimen and passage 3 virus were confirmed to be identical by Sanger sequencing. The beta, delta and omicron sequences have been submitted to Genbank.

The beta variant contained the following spike changes: L18F, D80A, D215G, del241-243, K417N, E484K, N501Y, D614G, and A701V. The delta variant contained the following spike changes: T19R, G142D, del156-157, R158G, A222V, L452R, T478K, D614G, P681R and D950N. The omicron variant contained the following spike mutations: A67VS, del69-70, T95I, G142-, del143-144, Y145D, del211, L212I, ins215EPE, G339D, S371L, S373P, S375F, K417N, N440K, G446S, S477N, T478K, E484A, Q493R, 
medRxiv preprint doi: https://doi.org/10.1101/2021.12.27.21268416; this version posted December 29, 2021. The copyright holder for this preprint (which was not certified by peer review) is the author/funder, who has granted medRxiv a license to display the preprint in perpetuity.

It is made available under a CC-BY 4.0 International license .

G496S, Q498R, N501Y, Y505H, T547K, D614G, H655Y, N679K, P681H, N764K, D796Y, N856K, Q954H,

134 N969K, L981F.

Detection of neutralizing antibodies by plaque reduction assay

137 Plaque reduction neutralization tests (PRNT) were performed as described previously $(1,6)$. Briefly, 138 heat-inactivated sera were two-fold diluted in OptiMEM medium starting at a dilution of 1:10 (or 1:80 139 for sera known to have more than $2500 \mathrm{BAU} / \mathrm{ml}$ S-specific binding antibodies) in 60ul. 400 plaque 140 forming units of different SARS-CoV-2 variants were added to each well in 60ul of virus suspension 141 incubated at $37^{\circ} \mathrm{C}$ for 1 hour. After 1 hour of incubation, the virus-antibody mixtures were transferred 142 onto the human airway cell line Calu-3 and incubated for 8 hours. After incubation, cells were fixed 143 and plaques were stained with polyclonal rabbit anti-SARS-CoV-2 nucleocapsid antibody (Sino 144 Biological) and a secondary peroxidase-labeled goat anti-rabbit lgG (Dako). Signal was developed by 145 using a precipitate-forming 3,3',5,5'-tetramethylbenzidine substrate (TrueBlue; Kirkegaard \& Perry 146 Laboratories) and the number of infected cells was counted per well by using an ImmunoSpot Image 147 Analyzer (CTL Europe $\mathrm{GmbH}$ ). The dilution that would yield 50\% reduction of plaques (PRNT50) 148 compared with the infection control was estimated by determining the proportionate distance 149 between two dilutions from which an endpoint titer was calculated. Raw data for neutralizing 150 antibodies early after vaccination (Supplemental Figure 2A, B), late after vaccination (Supplemental 151 Figure 2C, D), 6 months after positive PCR (Supplemental Figure 2E, 2F), or early after booster 152 vaccination (Supplemental Figure 2G, H) are included in the supplemental figures. Infection controls 153 and positive serum controls were included on each plate, the NIBSC standard was included in three 154 separate experiments. When no neutralization was observed, we set the PRNT50 one dilution step below the dilution series, i.e., a PRNT50 value of 10 .

\section{Overlapping SARS-CoV-2 Spike peptide pools}

158 SARS-CoV-2 peptides were synthesized as crude material (TC Peptide Lab, San Diego, CA). Overlapping

159 15-mer by 10 amino acids covering the full-length $S$ proteins from the WT, Beta (B.1.351), Delta

160 (B.1.617.2) and Omicron (B.1.1.529) variants were synthesized and individually resuspended in 161 dimethyl sulfoxide (DMSO) at a concentration of 10-20 mg/mL. Megapools (MP) for each spike variant 162 were generated by pooling aliquots of these individual peptides, undergoing another lyophilization, 163 and resuspending in DMSO at $1 \mathrm{mg} / \mathrm{mL}$ (7).

166 PBMCs were thawed in Gibco Roswell Park Memorial Institute 1640 medium (Gibco) supplemented 167 with 10\% human serum (Sanquin, Rotterdam), penicillin (100 IU/ml; Lonza, Belgium), streptomycin 
medRxiv preprint doi: https://doi.org/10.1101/2021.12.27.21268416; this version posted December 29, 2021. The copyright holder for this preprint (which was not certified by peer review) is the author/funder, who has granted medRxiv a license to display the preprint in It is made available under a CC-BY 4.0 International license.

168 (100 $\mu \mathrm{g} / \mathrm{ml}$; Lonza, Belgium), and $2 \mathrm{mM}$ L-glutamine (Lonza, Belgium; R10H medium) and treated with

169 Benzonase (50 IU/ml; Merck) at $37^{\circ} \mathrm{C}$ for $30 \mathrm{~min}$. Subsequently, $1 \times 10^{6}$ PBMCs were stimulated with SARS-CoV-2 variant peptide pools at $1 \mu \mathrm{g} / \mathrm{ml}$ per peptide in $200 \mu \mathrm{l}$ in a 96 -well U-bottom plate at $37^{\circ} \mathrm{C}$ for 20 hours. Cells were additionally stimulated with an equimolar concentration of DMSO (negative control) or a combination of phorbol 12 -myristate 13-acetate $(50 \mu \mathrm{g} / \mathrm{ml})$ and ionomycin $(500 \mu \mathrm{g} / \mathrm{ml})$ (positive control). Additionally, PBMC were stimulated with a peptide pool consisting of 176 known peptides for a broad range of HLA subtypes and different infectious agents (including human herpesviruses and influenza virus) as peptide positive control (PepMix CEFX Ultra SuperStim Pool, JPT). After stimulation, cells were stained for phenotypic lymphocyte markers.

\section{Detection of AIM by flow cytometry}

179 Detection of AIM was performed as described previously (1). Briefly, cells were stained with the

180 following antibodies in their respective dilutions: anti-CD3-PerCP (1:25, clone SK7, BD), anti-CD4-V50

181 (1:50, clone L200; BD), anti-CD8-fluorescein isothiocyanate (1:25, clone DK25; Dako), anti-CD45RA182 phycoerythrin (PE)-Cy7 (1:50, clone L48; BD), anti-CCR7-BV711, anti-CD69-allophycocyanin (APC)-H7 183 (1:50, clone FN50; BD), anti-CD137-PE (1:50, clone 4B4-1; Miltenyi), and anti-OX40-BV605 (1:25, clone 184 L106; BD). LIVE/DEAD Fixable Aqua Dead Cell staining was included (1:100, AmCyan; Invitrogen) and 185 acquired on a FACSLyric (BD Biosciences). SARS-CoV-2-specific T-cells were identified by gating the $186 \mathrm{CD}^{+} \mathrm{O} \times 40^{+} \mathrm{CD} 137^{+}$and $\mathrm{CD} 8^{+} \mathrm{CD} 69^{+} \mathrm{CD} 137^{+}$cells. The DMSO-stimulated sample was used to set the cutoff gate for activation markers. On average, 500,000 cells were acquired per sample.

\section{Statistical analysis}

A comparison of the baseline characteristics age and interval between vaccination between groups was performed by Kruskal-Wallis with multiple comparisons. Reduction in binding and neutralizing antibody levels over time within groups was analyzed by paired $T$ test. Different groups were compared by unpaired T test. Differences in PRNT50 and T-cell responses to VOC were estimated by Friedman

194 test with multiple comparisons, data was not normally distributed. Spearman R was calculated for the correlation between binding and neutralizing antibodies. All statistical analyses were performed on log-transformed data.

\section{Software}

199 Statistical analyses were performed with Graphpad PRISM version 9.1.2. Expression of AIM was analysed with FlowJo software version 10.8.1. 
medRxiv preprint doi: https://doi.org/10.1101/2021.12.27.21268416; this version posted December 29, 2021. The copyright holder for this preprint (which was not certified by peer review) is the author/funder, who has granted medRxiv a license to display the preprint in It is made available under a CC-BY 4.0 International license .

\section{Supplemental Tables}

203

204 Supplemental Table 1. Cohort background. A total of 438 participants from three different trials 205 (HCW, ConCOVID, SWITCH) were included in this study. ${ }^{*} \mathrm{~N}=9$ participants of the HCW study were 206 additionally analysed 14 days after the $3^{\text {rd }}$ vaccination. ${ }^{\S} \mathrm{Ad} 26 . \mathrm{COV} 2 . \mathrm{S}$ samples were analysed 56 days 207 and 6 months after $1^{\text {st }}$ vaccination. ${ }^{\#}$ T-cell responses were exclusively assessed in participants of the 208 HCW study for vaccine regimen comparisons.

\begin{tabular}{|c|c|c|c|}
\hline Study & Objective & Participants $^{\#}$ & Timepoints \\
\hline $\mathrm{HCW}$ & Vaccine regimen comparison & $N=400$ & $\begin{array}{l}28 \text { days and } 6 \text { months post } \\
\text { vaccination*§ }\end{array}$ \\
\hline ConCOVID & Convalescent patients & $N=23$ & 6 months post infection \\
\hline SWITCH & Heterologous vaccination & $N=15$ & 28 days post $2^{\text {nd }}$ vaccination \\
\hline
\end{tabular}


medRxiv preprint doi: https://doi.org/10.1101/2021.12.27.21268416; this version posted December 29, 2021. The copyright holder for this preprint (which was not certified by peer review) is the author/funder, who has granted medRxiv a license to display the preprint in It is made available under a CC-BY 4.0 International license.

\section{Supplemental Figures}

211

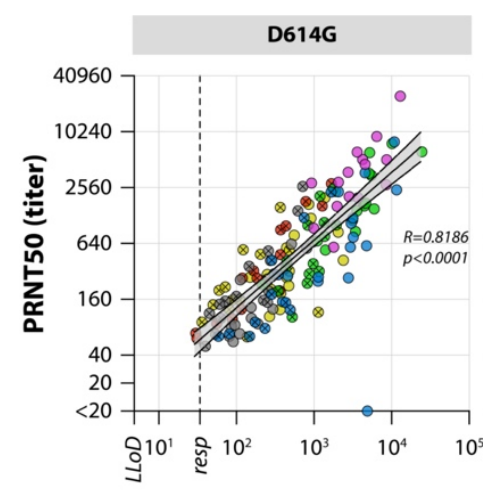

$\mathrm{g}^{10^{1}} \stackrel{\mathrm{\Xi}}{\mathrm{e}}$

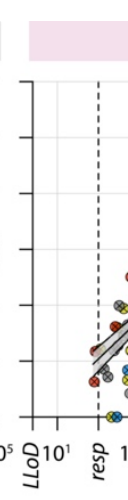

Delta



Beta

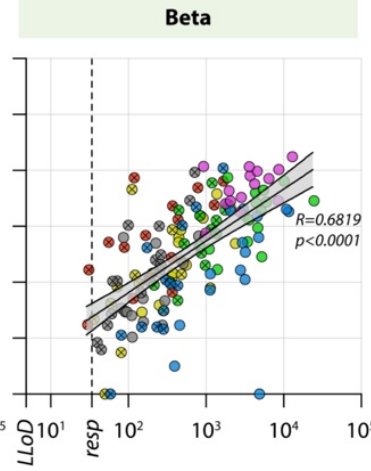

$g^{10^{\prime}} \check{\Xi}^{10}$
Omicron



10

Supplemental Figure 1. Correlation between neutralizing antibodies and S-specific binding

214 antibodies. Correlation between S-specific biding antibodies early (open symbols) and late (symbols

215 with cross) after vaccination or infection with D614G-specific, Delta-specific, Beta-specific, or Omicron-

216 specific neutralizing antibodies. For S-specific binding antibodies the LLoD is $4.81 \mathrm{BAU} / \mathrm{ml}$, responder

217 (resp) cut-off is $33.8 \mathrm{BAU} / \mathrm{ml}$ (dotted line). For neutralizing antibodies, the lowest serum dilution tested

218 was $1: 20$, undetectable PRNT50 values $(<20)$ were set at a PRNT50 of 10 . LLoD = lower limit of

219 detection, $\mathrm{BAU}=$ binding arbitrary units, PRNT50 = plaque reduction neutralization titer $-50 \%$.

220 Spearman $\mathrm{R}$ was calculated on basis of log-transformed data. 
medRxiv preprint doi: https://doi.org/10.1101/2021.12.27.21268416; this version posted December 29, 2021. The copyright holder for this preprint (which was not certified by peer review) is the author/funder, who has granted medRxiv a license to display the preprint in It is made available under a CC-BY 4.0 International license.
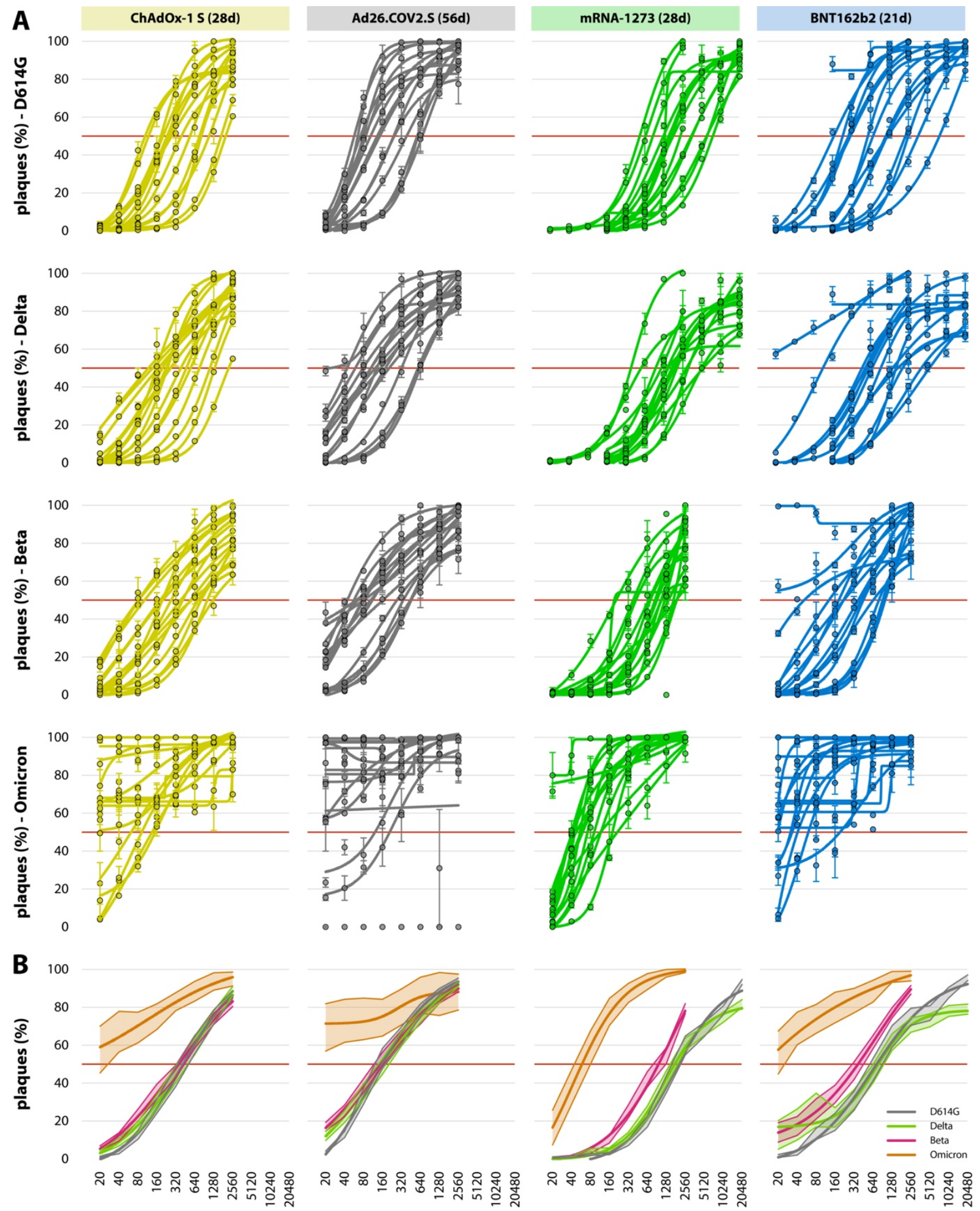
medRxiv preprint doi: https://doi.org/10.1101/2021.12.27.21268416; this version posted December 29, 2021. The copyright holder for this preprint (which was not certified by peer review) is the author/funder, who has granted medRxiv a license to display the preprint in It is made available under a CC-BY 4.0 International license.

medRxiv preprint doi: https://doi.org/10.1101/2021.12.27.21268416; this version posted December 29, 2021. The copyright holder for this preprint (which was not certified by peer review) is the author/funder, who has granted medRxiv a license to display the preprint in It is made available under a CC-BY 4.0 International license.
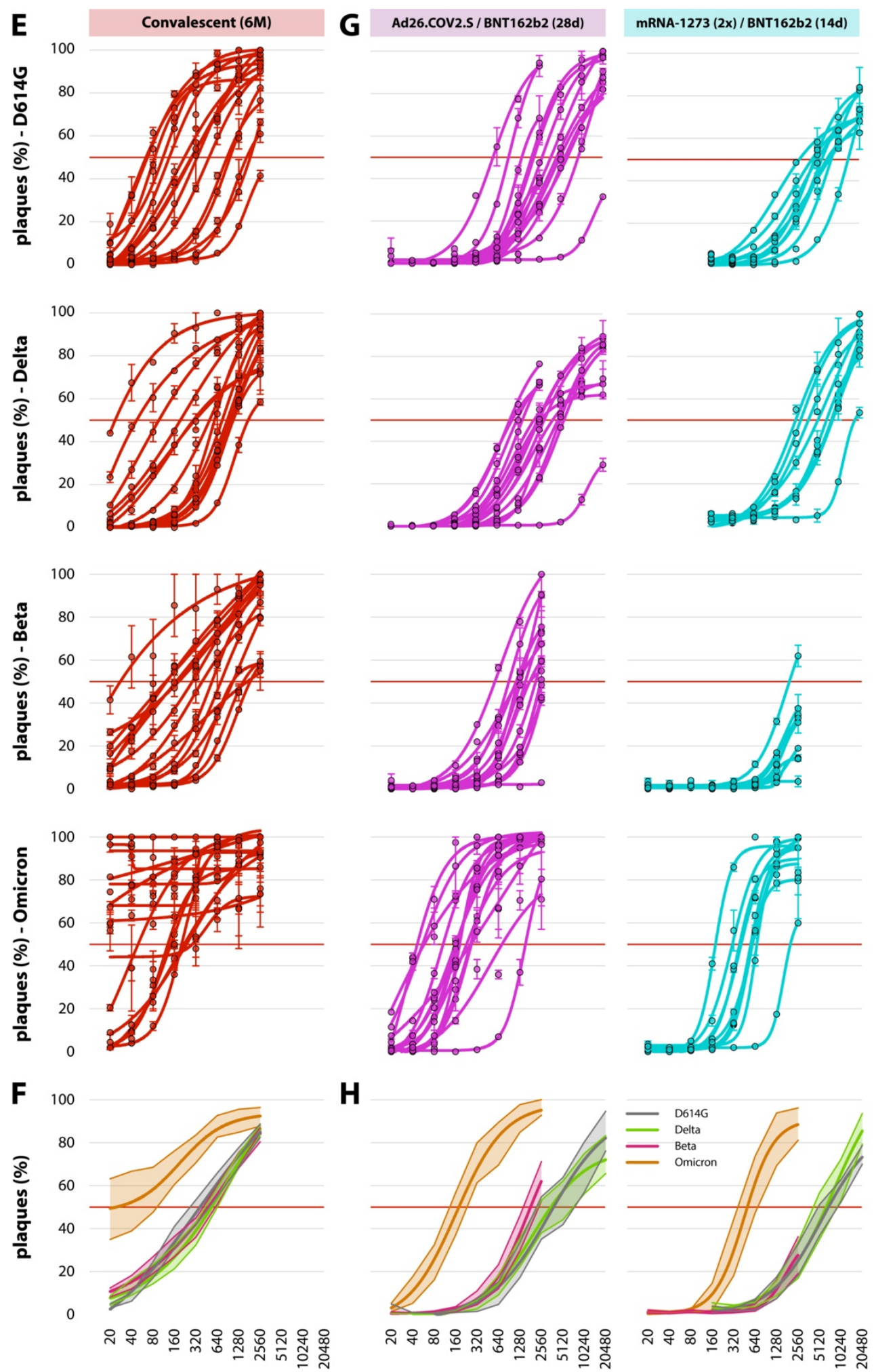

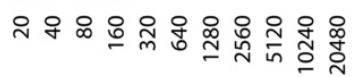

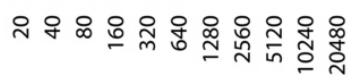

227 Supplemental Figure 2. PRNT50 calculations. Graphs in panels A, C, E, and G show per participant $228 \log$ (inhibitor) versus responses curves with four parameter variable slopes based on plaque counts 229 compared to the virus control, for the four different variants. Panels B, D, F, and H show the average 230 curves from all participants with the $95 \% \mathrm{Cl}$. Neutralizing antibodies $(\mathrm{A}, \mathrm{B})$ early after vaccination, $(\mathrm{C}, \mathrm{D})$ 231 late after vaccination, $(E, F) 6$ months after infection, and $(G, H)$ early after booster vaccination. 
medRxiv preprint doi: https://doi.org/10.1101/2021.12.27.21268416; this version posted December 29, 2021. The copyright holder for this preprint (which was not certified by peer review) is the author/funder, who has granted medRxiv a license to display the preprint in It is made available under a CC-BY 4.0 International license.

\section{References}

234 1. D. Geers, M. C. Shamier, S. Bogers, G. den Hartog, L. Gommers, N. N. Nieuwkoop, K. S. Schmitz, L. C. Rijsbergen, J. A. T. van Osch, E. Dijkhuizen, G. Smits, A. Comvalius, D. van Mourik, T. G. Caniels, M. J. van Gils, R. W. Sanders, B. B. Oude Munnink, R. Molenkamp, H. J. de Jager, B. L. Haagmans, R. L. de Swart, M. P. G. Koopmans, R. S. van Binnendijk, R. D. de Vries, C. H. GeurtsvanKessel, SARS-CoV-2 variants of concern partially escape humoral but not T-cell responses in COVID-19 convalescent donors and vaccinees. Sci Immunol 6, (2021).

2. A. Gharbharan, C. C. E. Jordans, C. GeurtsvanKessel, J. G. den Hollander, F. Karim, F. P. N. Mollema, J. E. Stalenhoef-Schukken, A. Dofferhoff, I. Ludwig, A. Koster, R. J. Hassing, J. C. Bos, G. R. van Pottelberge, I. N. Vlasveld, H. S. M. Ammerlaan, E. M. van Leeuwen-Segarceanu, J. Miedema, M. van der Eerden, T. J. Schrama, G. Papageorgiou, P. Te Boekhorst, F. H. Swaneveld, Y. M. Mueller, M. W. J. Schreurs, J. J. A. van Kampen, B. Rockx, N. M. A. Okba, P. D. Katsikis, M. P. G. Koopmans, B. L. Haagmans, C. Rokx, B. J. A. Rijnders, Effects of potent neutralizing antibodies from convalescent plasma in patients hospitalized for severe SARS-CoV-2 infection. Nat Commun 12, 3189 (2021).

3. R. S. G. Sablerolles, W. J. R. Rietdijk, A. Goorhuis, D. F. Postma, L. G. Visser, D. Geers, K. S. Schmitz, H. M. Garcia Garrido, M. P. G. Koopmans, V. A. S. H. Dalm, N. A. Kootstra, A. L. W. Huckriede, M. Lafeber, D. van Baarle, C. GeurtsvanKessel, R. D. de Vries, P. H. M. van der Kuy, Immunogenicity and reactogenicity of booster vaccinations after Ad26.COV.2.S priming.

4. J.-S. Sanders, F. J. Bemelman, A. L. Messchendorp, C. C. Baan, D. Van Baarle, R. van Binnendijk, MedRxiv, (2021).

5. M. M. Lamers, J. Beumer, J. van der Vaart, K. Knoops, J. Puschhof, T. I. Breugem, R. B. G. Ravelli, D. A. Diavatopoulos, S. C. Frolke, D. Geers, C. GeurtsvanKessel, G. Den Hartog, M. van der Heiden, C. Imhof, M. M. L. Kho, M. P. G. Koopmans, S. Reshwan K Malahe, W. B. Mattheussens, R. Van der Molen, D. Van Mourik, E. B. M. Remmerswaal, N. Rots, P. Vart, R. D. de Vries, R. T. Gansevoort, L. B. Hilbrands, M. E. J. Reinders, The RECOVAC Immune-Response Study The immunogenicity, tolerability and safety of COVID-19 vaccination in patients with chronic kidney disease, on dialysis, or living with a kidney transplant. Transplantation forthcoming, (2021).

266 6. N. M. A. Okba, M. A. Muller, W. Li, C. Wang, C. H. GeurtsvanKessel, V. M. Corman, M. M. J. Paul van Schayck, A. Z. Mykytyn, H. Q. Duimel, E. van Donselaar, S. Riesebosch, H. J. H. Kuijpers, D. Schipper, W. J. van de Wetering, M. de Graaf, M. Koopmans, E. Cuppen, P. J. Peters, B. L. Haagmans, H. Clevers, SARS-CoV-2 productively infects human gut enterocytes. Science 369, 50-54 (2020).

Lamers, R. S. Sikkema, E. de Bruin, F. D. Chandler, Y. Yazdanpanah, Q. Le Hingrat, D. Descamps, 
medRxiv preprint doi: https://doi.org/10.1101/2021.12.27.21268416; this version posted December $29,2021$. The copyright holder for this preprint (which was not certified by peer review) is the author/funder, who has granted medRxiv a license to display the preprint in It is made available under a CC-BY 4.0 International license.

N. Houhou-Fidouh, C. Reusken, B. J. Bosch, C. Drosten, M. P. G. Koopmans, B. L. Haagmans, Severe Acute Respiratory Syndrome Coronavirus 2-Specific Antibody Responses in Coronavirus Disease Patients. Emerg Infect Dis 26, 1478-1488 (2020).

7. A. Tarke, J. Sidney, N. Methot, E. D. Yu, Y. Zhang, J. M. Dan, B. Goodwin, P. Rubiro, A. Sutherland, E. Wang, A. Frazier, S. I. Ramirez, S. A. Rawlings, D. M. Smith, R. da Silva Antunes, 2 variants on the total $\mathrm{CD} 4(+)$ and $\mathrm{CD} 8(+) \mathrm{T}$ cell reactivity in infected or vaccinated individuals. 